\title{
Un cortile per una nuova capitale
}

\author{
Pamela Maiezza
}

Abstract

II trasferimento della capitale a Roma, in seguito all'annessione al Regno d'Italia della Città dei Papi, pose il problema dell'individuazione degli spazi dove ospitare gli organi amministrativi dello Stato. Superata una prima fase segnata dall'urgenza di rendere effettivo l'insediamento del governo nazionale - nella quale vennero impiegate le sedi dello Stato Pontificio oppure edifici di provenienza ecclesiastica riadattati - emerse la necessità di compiere delle scelte strategiche per la costituzione di Roma Capitale.

I| Palazzo delle Finanze (| 87| - |876), costruito per volere del ministro Quintino Sella da un gruppo di progettisti coordinato da Raffaele Canevari, costituisce la prima opera pubblica realizzata ex novo per rispondere all'istanza funzionale e, allo stesso tempo, rappresentativa del nuovo stato unitario.

II contributo proposto presenta lo studio condotto sul Palazzo, focalizzando l'attenzione sul cortile centrale disegnato da Francesco Pieroni. Sulla base del rilievo architettonico, si propone una lettura storico-critica del cortile attraverso, in particolare, l'analisi proporzionale dell'ordine architettonico del loggiato.

Parole chiave

documentazione, rilievo architettonico, analisi proporzionale, Roma Capitale, Palazzo delle Finanze.

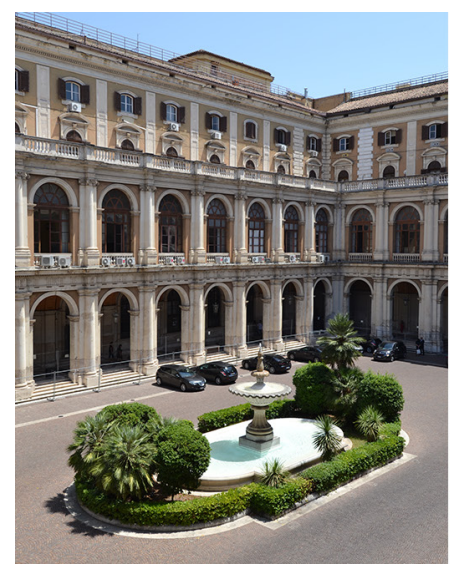

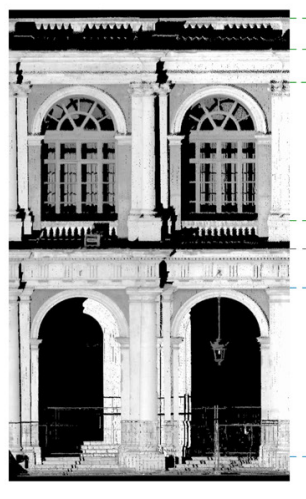

3835

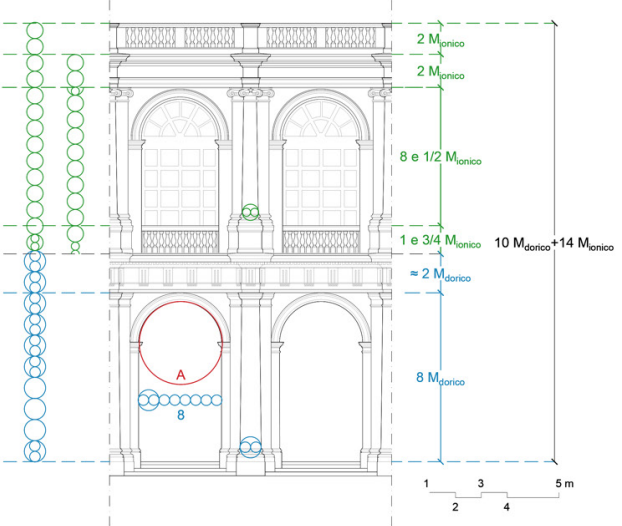




\section{Introduzione}

II trasferimento della capitale da Firenze a Roma del I87I, seguito all'annessione al Regno d'Italia della Città dei Papi, pose il problema dell'individuazione degli spazi dove ospitare gli organi amministrativi dello Stato.

A una prima fase contraddistinta dall'urgenza di rendere effettivo l'insediamento del governo nazionale italiano, nella quale vennero impiegate le sedi dello Stato Pontificio oppure, in via provvisoria, edifici di provenienza ecclesiastica riadattati, ne seguì una più riflessiva e programmatica, in cui emerse la necessità di compiere delle scelte strategiche per la costituzione di Roma Capitale [Borsi 1989; Salsano 2012].

II Palazzo delle Finanze, costruito tra il | 87 | e il 1876 ad opera di un gruppo di progettisti coordinato da Raffaele Canevari, rappresenta la prima opera pubblica realizzata ex novo per rispondere a tale esigenza (fig. I).

Fortemente voluto da Quintino Sella, ministro delle finanze dal 1862 che di questo periodo fu indiscusso protagonista, il Palazzo esemplifica la sua idea della Pubblica Amministrazione e della Roma Capitale. Non solo semplice committente del proprio ministero, infatti, Sella rivestì un ruolo di primaria importanza nella costruzione del Palazzo delle Finanze, partecipando attivamente al suo processo realizzativo, tanto da far sorgere il dubbio sulla paternità dell'edificio: è 'Quintino Sella, 'ingegnere' nel bene e nel male, cui probabilmente questa opera dovrebbe essere ascritta. Sue le scelte urbanistiche, altrettanto quella degli architetti e del gruppo di lavoro che vi intervennero, forse [... . sua in qualche modo l'indicazione del linguaggio neo-cinquecentista da adottare" [Spagnesi 1989, p. 94].

Nell'ambito della Convenzione stipulata nel 2017 tra l'Università degli Studi dell'Aquila e il Ministero dell'Economia e delle Finanze relativa allo Studio del comportamento sotto carichi sismici dell'edificio del Ministero dell'Economia e delle Finanze in via XX Settembre - Roma (responsabile scientifico prof. Angelo Luongo), è stato realizzato il rilievo architettonico del cortile centrale del Palazzo, della galleria del primo piano nei due bracci accessibili e della Sala della Maggioranza, oggi denominata sala Ciampi.

I| contributo proposto presenta parte degli esiti di tale studio, focalizzando l'attenzione sul cortile centrale disegnato da Francesco Pieroni. Nello specifico, sulla base del rilievo architettonico si propone una lettura storico-critica del cortile attraverso, in particolare, l'analisi proporzionale dell'ordine architettonico del loggiato.

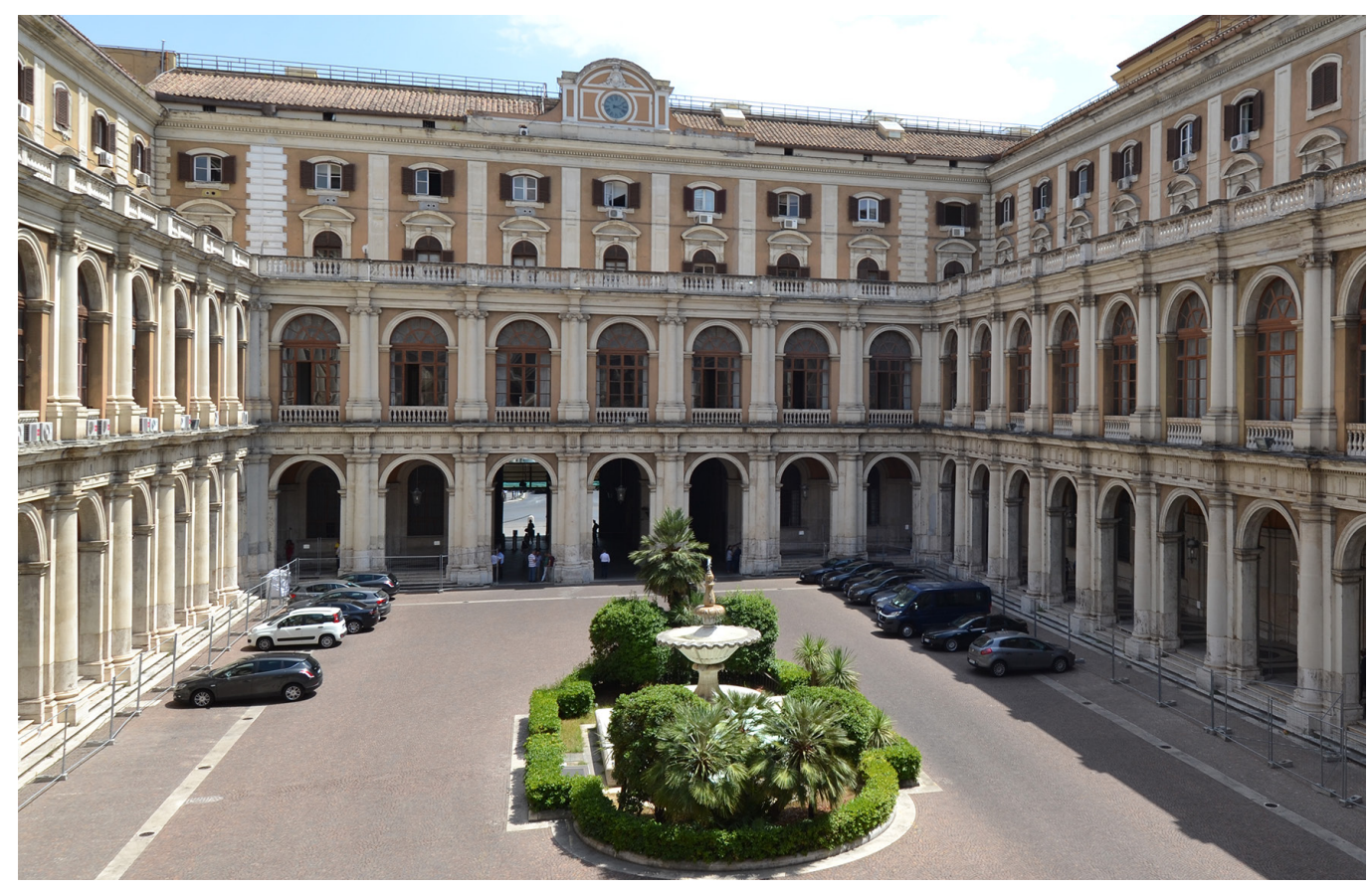




\section{Dalla Roma dei Papi a Roma Capitale: la costruzione del Palazzo delle Finanze}

La realizzazione del Palazzo delle Finanze si inserisce all'interno del dibattito sulle modalità da seguire per la costituzione della Roma Capitale, che vede contrapporsi due differenti orientamenti: il primo basato sul riadattamento di vecchi immobili espropriati, e motivato da ragioni economiche e di urgenza; l'altro incentrato sulla creazione di un nuovo centro direzionale lungo l'asse di via XX Settembre, quale simbolo dell'Italia unita e della sua nuova capitale [Tabarrini $20 \mathrm{ll}$ ]. Questo secondo approccio, sostenuto dalla prima Commissione per il trasferimento della capitale oltre che dal potente ministro Sella, va a interferire, inevitabilmente, con i programmi urbani per l'ampliamento della città verso est, portati avanti in autonomia dall'amministrazione capitolina. II progetto del nuovo quartiere Macao, infatti, avviato a partire dal 1860 in relazione alla nuova stazione a Termini, dovrà necessariamente mutare per piegarsi alla scelta del Sella di collocare il gigantesco edificio del Ministero nel cuore del quartiere, lungo via $X X$ Settembre.

La progettazione dell'edificio venne inizialmente affidata all'ingegnere milanese Luigi Tatti, affiancato dal romano Raffaele Canevari. Sebbene Tatti, tra l'ottobre e il novembre del I 87 I, venne sollevato dall'incarico, è all'ingegnere milanese che si deve l'ubicazione esatta del nuovo edificio all'interno del quartiere Macao e, soprattutto, la soluzione tipologica della reggia che verrà poi adottata nel progetto definitivo.

L'incarico per il Ministero delle Finanze passò quindi a Canevari, ingegnere ferroviario ed idraulico dalla scarsa esperienza nel settore architettonico che, però, aveva dalla sua parte una buona conoscenza di Roma e dei progetti municipali, derivatagli dal suo coinvolgimento nel dibattito sullo sviluppo urbano portato avanti dall'amministrazione comunale. Nell'ottobre del 1872 gli vengono affiancati due architetti, Luigi Martinori e Francesco Pieroni, autori, rispettivamente, delle facciate esterne e del cortile centrale.

Se di Marinori non si conoscono altri lavori, Pieroni aveva all'attivo già diversi interventi di edilizia corrente quando venne chiamato a collaborare alla realizzazione del Ministero. Tuttavia, nonostante l'alta considerazione che avevano di lui i suoi contemporanei, le sue opere non dimostrano le qualità di un architetto che si distingua rispetto a tanti suoi colleghi: raffinato rilevatore di monumenti quale era (aveva lavorato con Letarouilly), Pieroni va considerato più un disegnatore che un progettista in grado di proporre soluzioni per un'opera tanto complessa come il Palazzo delle Finanze [Spagnesi 1989].

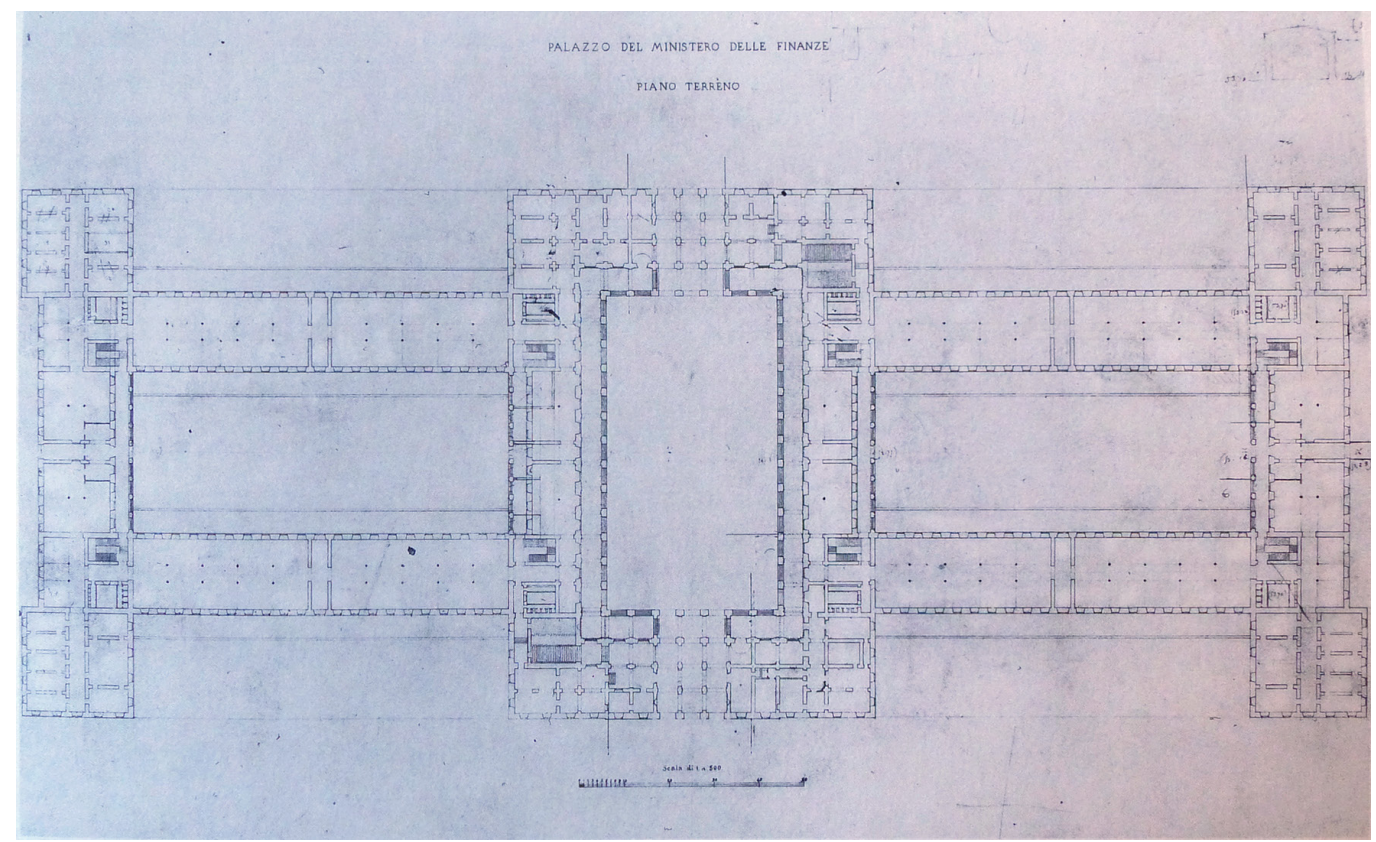


Appare allora chiara l'impostazione del gruppo di lavoro con la relativa ripartizione dei ruoli, voluta dallo stesso Sella: decisa la tipologia del nuovo edificio dal Tatti, a Canevari spetterà la definizione dell'impianto distributivo e strutturale e la responsabilità del cantiere, mentre ai due architetti toccherà il disegno dei dettagli del linguaggio architettonico.

Canevari propose tre diversi soluzioni progettuali, ognuna articolata in più varianti, prima di arrivare alla configurazione definitiva: un impianto planimetrico caratterizzato da un andamento longitudinale dovuto alla forma rettangolare allungata delle due corti laterali, separate dal cortile d'onore che, invece, risulta caratterizzato da una giacitura trasversale datagli dall'avanzamento dei fronti sino al filo delle quattro torri angolari [Polla 1979] (fig. 2).

Per quanto concerne il linguaggio architettonico prescelto, non si tentò di proporre una figuratività del tutto nuova ma, piuttosto, si preferì rifarsi al linguaggio neo-cinquecentista, in continuità con quel 'purismo' romano che aveva caratterizzato l'architettura durante il pontificato di Pio IX (fig. 3).

I lavori iniziarono il $1{ }^{\circ}$ aprile 1872, quando ancora il progetto non aveva assunto la sua forma definitiva.

Sin da subito, però, Carnevari si trovò ad affrontare gravi problemi, legati in particolare alle fondazioni dell'edificio. La presenza di importanti preesistenze archeologiche - come, del resto, era owvio aspettarsi - e di vuoti (grotte naturali o cunicoli scavati), tipici del terreno romano, richiesero delle fondazioni più profonde rispetto a quelle preventivate, portando così a notevoli ritardi al cantiere e ad un cospicuo aumento delle spese.

Data l'urgenza di insediare gli uffici ministeriali nel nuovo edificio il primo possibile, un primo collaudo delle parti già ultimate venne effettuato il 12 settembre 1876. L'inaugurazione del Palazzo delle Finanze, ancora incompleto, ebbe luogo il 3 settembre 1877, mentre un secondo collaudo provvisorio si avrà il I 6 luglio | 878. Solo il 6 giugno | 88 I, invece, fu eseguito il collaudo definitivo dell'intero edificio.

Al termine dei lavori, l'idea di Sella di costituire un nuovo centro amministrativo sull'asse tra Porta Pia e il Quirinale (lungo via XX Settembre), di cui il Palazzo delle Finanze doveva costituire solo il primo passo seppur il principale, venne abbandonata a causa della mancanza di fondi, ormai esauriti.

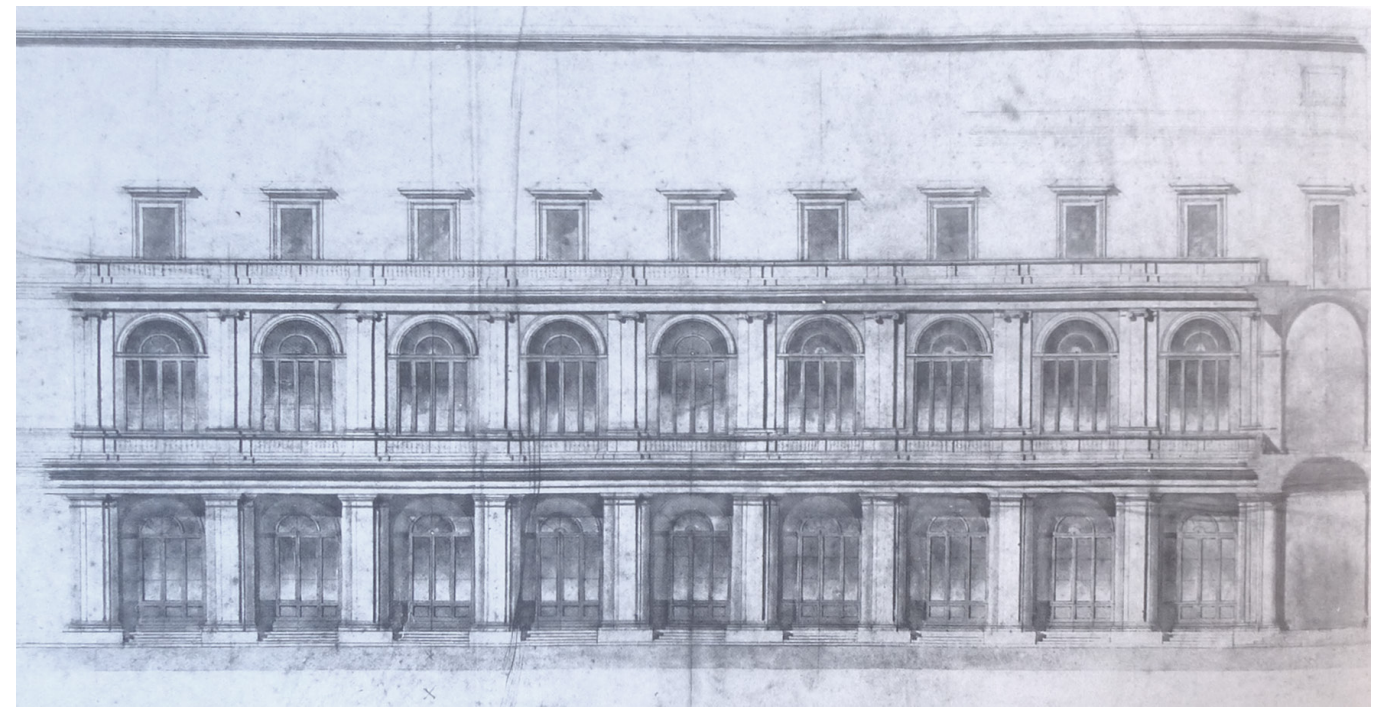

\section{II rilievo architettonico}

La campagna di rilievo del Palazzo delle Finanze è stata condotta con l'ausilio dello scanner laser a differenza di fase Leica HDS6200, caratterizzato da un campo visivo completo (FOV) di $360^{\circ} \times 310^{\circ}$ (fig. 4). 
Fig. 4. Vista della nuvola di punti del cortile.

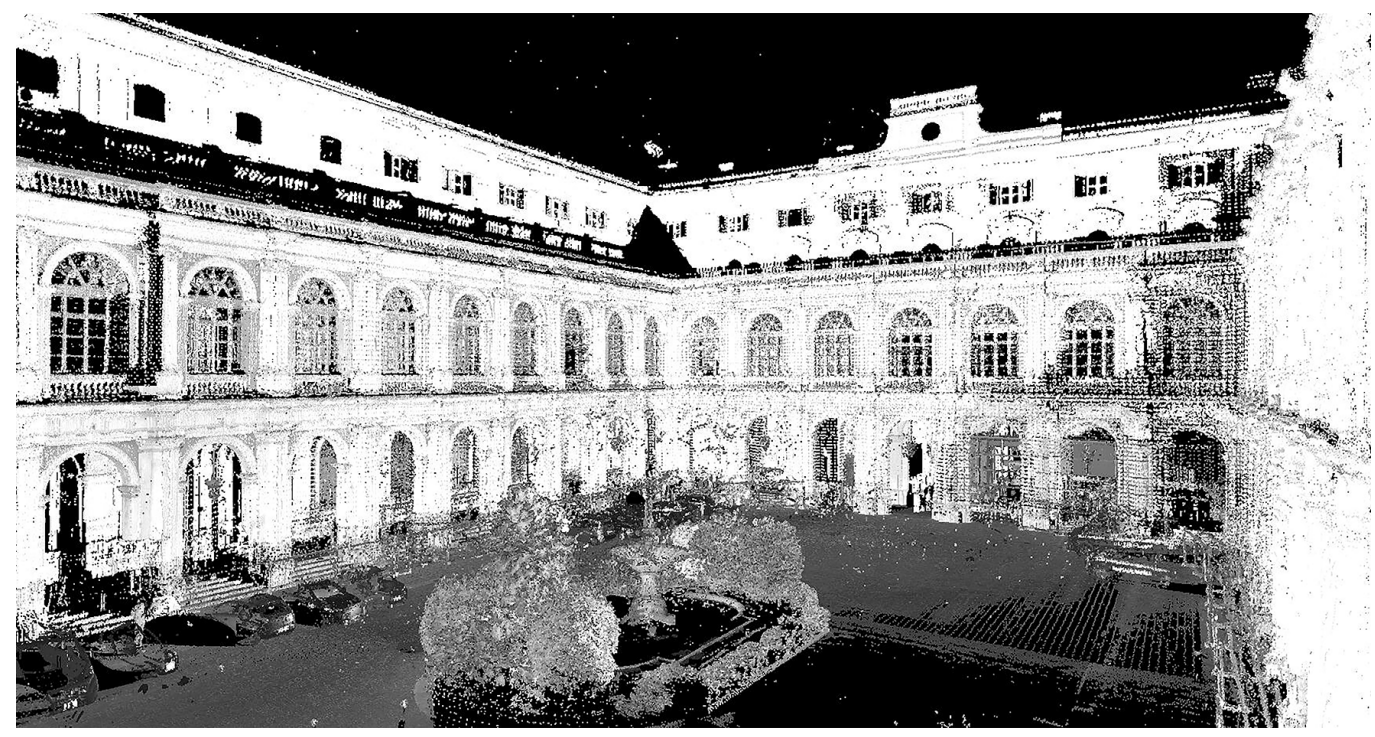

Il progetto di rilievo, con la definizione delle stazioni di presa e della risoluzione di scansione, è stato condizionato dall'esigenza di ridurre quanto più possibile i tempi di acquisizione dei dati. Avendo a disposizione un lasso di tempo limitato per poter accedere agli spazi del Ministero, si rendeva infatti necessaria un'ottimizzazione dei tempi di scansione senza, però, perdere in accuratezza della scansione o completezza delle informazioni.

In considerazione delle caratteristiche geometrico-dimensionali degli ambienti da rilevare, si è scelto di adottare per il cortile e la sala Ciampi il livello di risoluzione alto (corrispondente a un incremento di angolo azimutale e zenitale di $0,036^{\circ}$ e una distanza tra i punti, per esempio, di $1,59 \mathrm{~cm}$ a $25 \mathrm{~m}$ ), e quello medio (incremento di angolo azimutale e zenitale di $0,072^{\circ}$ e una densità di punti di $3,14 \mathrm{~cm}$ a $25 \mathrm{~m}$ ) per la galleria del primo piano.

Complessivamente sono state realizzate 18 scansioni così ripartite: 9 riprese laser nella galleria del primo piano; 3 dentro la sala Ciampi; 6 all'interno del cortile.
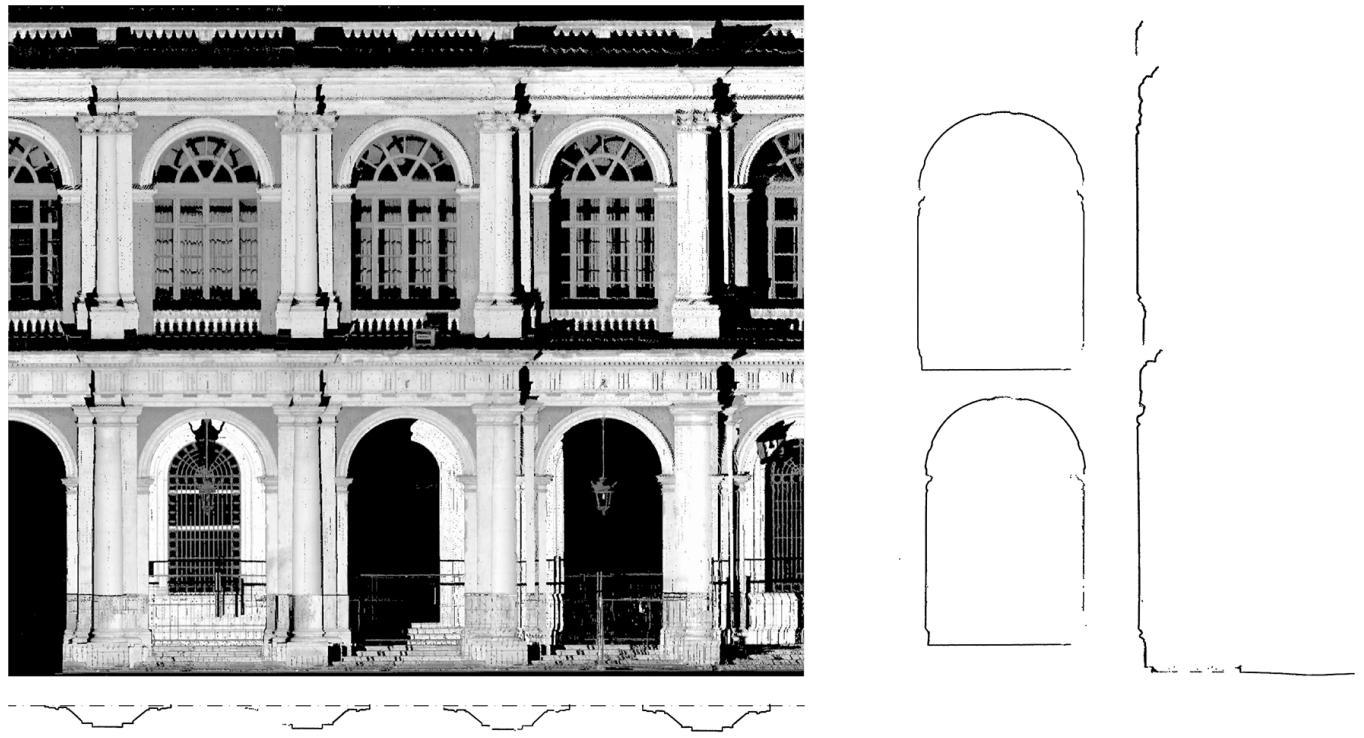

Fig. 5. Nuvola di punti del loggiato: ortofoto, sezione verticale ed orizzontale.

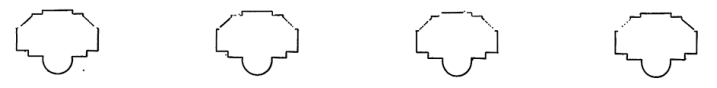


La registrazione delle singole scansioni è stata effettuata prevalentemente mediante procedure di riconoscimento automatico dei target mobili, posizionati prima delle riprese in modo che fossero visibili da due scansioni adiacenti. Nello specifico, sono stati impiegati target del tipo Black \& White da 6"Tilt \& Turn che assicurano una visibilità frontale da ogni stazione di presa.

Per il collegamento tra esterno e interno, invece, non essendo stato possibile l'inserimento di un numero sufficiente di target, si è proceduto con operazioni di registrazione manuale, consistenti nell'individuare una serie di punti omologhi tra le due points-cloud ottenute dalle registrazioni automatiche delle scansioni dell'interno e dell'esterno.

La nuvola di punti complessiva così ottenuta è stata poi impiegata per la realizzazione dei disegni restitutivi bidimensionali (fig. 5). Per la rappresentazione in pianta, in particolare, la nuvola è stata sezionata con un piano di taglio passante ad un'altezza di due metri rispetto
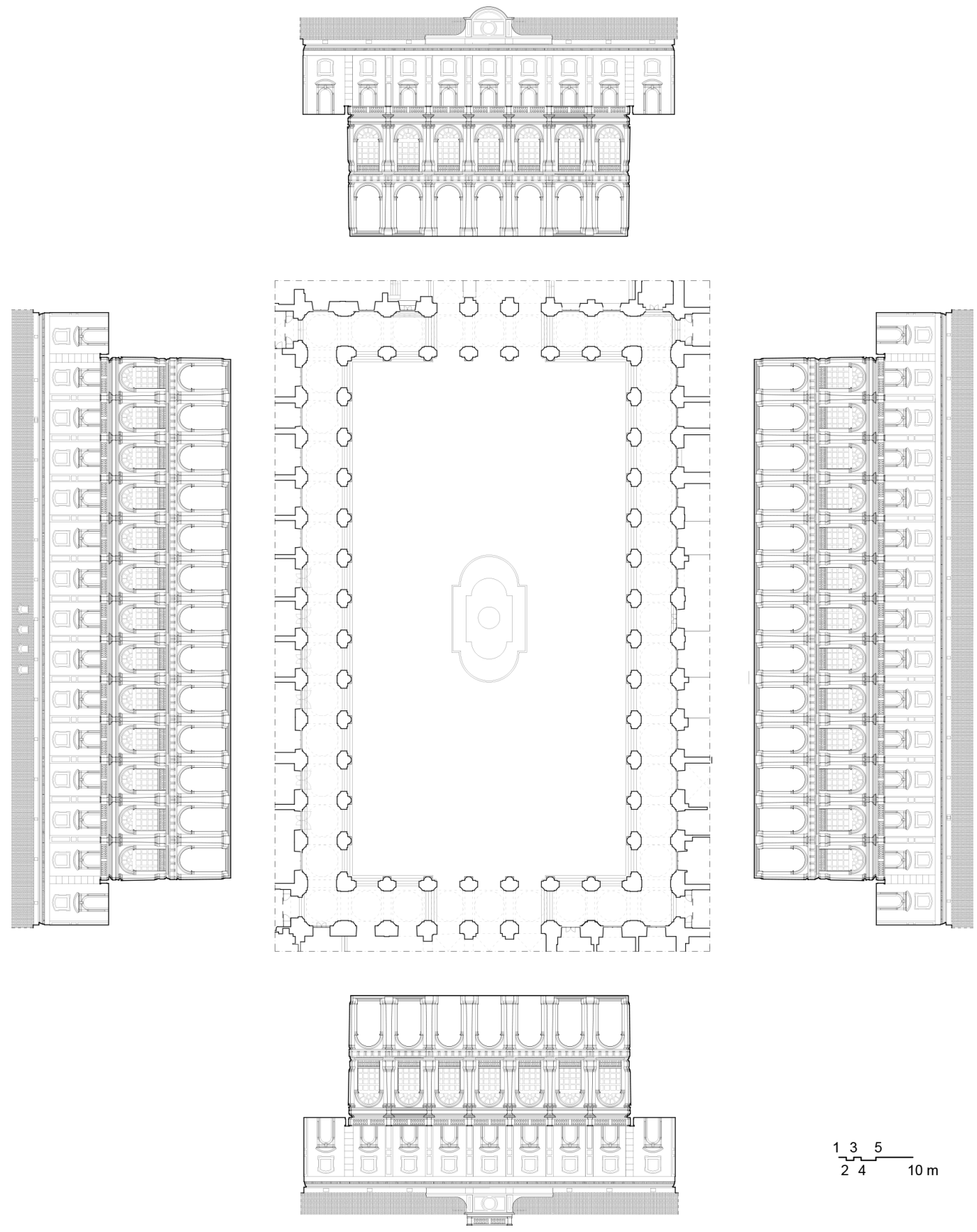
alla quota della pavimentazione del cortile. Le porzioni proiettate sono state invece disegnate sulla base dell'orto-immagine ricavata dalla nuvola di punti attraverso il medesimo piano di sezione. I prospetti sul cortile, invece, sono stati ottenuti facendo passare dei piani di sezione paralleli alle singole facciate di interesse: la slice della nuvola di punti è servita di supporto per l'individuazione dei profili degli elementi architettonici e delle modanature; l'orto-immagine è stata invece utilizzata per il disegno dell'ordine architettonico in proiezione ortogonale (fig. 6).

\section{Il cortile centrale: analisi e proporzioni della corte d'onore}

La grande corte di rappresentanza disegnata da Francesco Pieroni costituisce il fulcro attorno al quale gravita l'intero impianto planimetrico del Palazzo delle Finanze: giocata sull'articolazione delle corti, la pianta risulta infatti segnata da un forte asse trasversale costituito dal cortile centrale, che va a contrapporsi alla giacitura longitudinale dell'edificio.

Osservando i diversi progetti disegnati per il Palazzo delle Finanze, appare chiara l'evoluzione del ruolo del cortile centrale, da semplice slargo con una mera valenza funzionale a vera e propria corte d'onore: se nel primo progetto ( I87I) i cortili laterali, di forma quadrata e dalle grandissime dimensioni, sono distanziati appena da una strettissima corte centrale, già nel secondo progetto ( $187 \mid$ ) questa diviene più importante, con un impianto cruciforme molto sporgente sui fronti (prima variante), oppure allineato alle torri angolari (seconda variante); nel terzo progetto si rinuncia all'articolazione della corte che rimane, tuttavia, ancora piuttosto stretta e angusta, per arrivare, infine, nella seconda variante, alla sua forma definitiva con delle proporzioni tali da farne il cortile di rappresentanza dell'edificio [Spagnesi 1989].

Per la definizione del linguaggio architettonico delle facciate sulla corte vengono elaborate diverse ipotesi che, però, mantengono inalterata l'idea di fondo di un loggiato a due piani risolto con un doppio ordine sovrapposto oppure con un ordine gigante ad incorniciare due livelli di arcate. Tra le varie possibilità, alla fine, si decise per la sovrapposizione dell'ordine ionico al dorico, soluzione questa prescelta già prima dell'entrata in scena del Pieroni, al quale, pertanto, venne affidato solo il suo disegno definitivo.

Formatosi rilevando i monumenti dell'architettura rinascimentale romana, Pieroni propose una soluzione piuttosto scolastica mutuata sui modelli del maturo Cinquecento.

I fronti prospicienti il cortile presentano un passo regolare scandito da un ritmo costante su tutti e quattro i lati, fatta eccezione per la campata all'angolo, di poco più stretta (circa $10 \mathrm{~cm}$ ).

Fig. 7. Analisi proporzionale del loggiato: l'altezza misurata dalla base dei piedritti sino alla trabeazione del secondo ordine è uguale a 5 volte la luce delle arcate (modulo A); partendo invece dalla base della colonna centrale, il portico è alto tre volte l'interasse dei pilastri (modulo B).

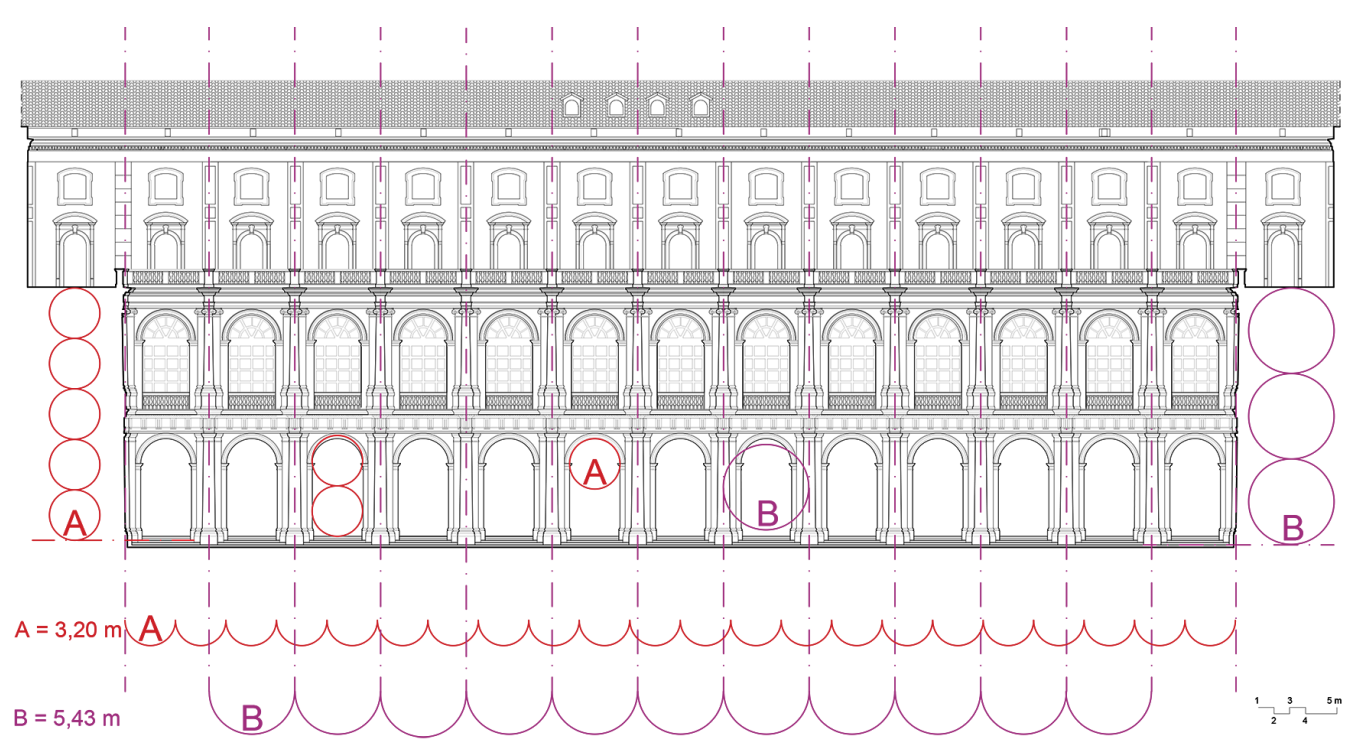


Fig. 8. Le proporzioni del doppio ordine architettonico: modulo dorico $(82 \mathrm{~cm})$, modulo onico $(63 \mathrm{~cm})$ e roporzione armonica $(6,8,12)$.
L'ordine dorico incornicia le arcate del porticato del piano terra, mentre il secondo ordine, in stile ionico con piedistallo, va a riquadrare le grandi finestre ad arco del primo livello. Entrambi gli ordini presentano una base attica (fig. 9).

Definito come modulo A la luce delle arcate, l'altezza del loggiato misurata dalla base dei piedritti sino alla trabeazione del secondo ordine è uguale a 5 moduli. Partendo invece dalla base della colonna centrale, il loggiato è alto tre volte l'interasse dei pilastri (modulo B), (fig. 7). Le proporzioni dell'ordine sono quelle classiche rintracciabili nei trattati architettonici rinascimentali, fatto salvo per alcune eccezioni.

In particolare, prendendo come modulo il diametro della colonna valutato all'imoscapo (pari a $82 \mathrm{~cm}$ ), l'ordine dorico misura 8 moduli dalla base fino al capitello e quasi 2 moduli per la trabeazione (fig. 8).

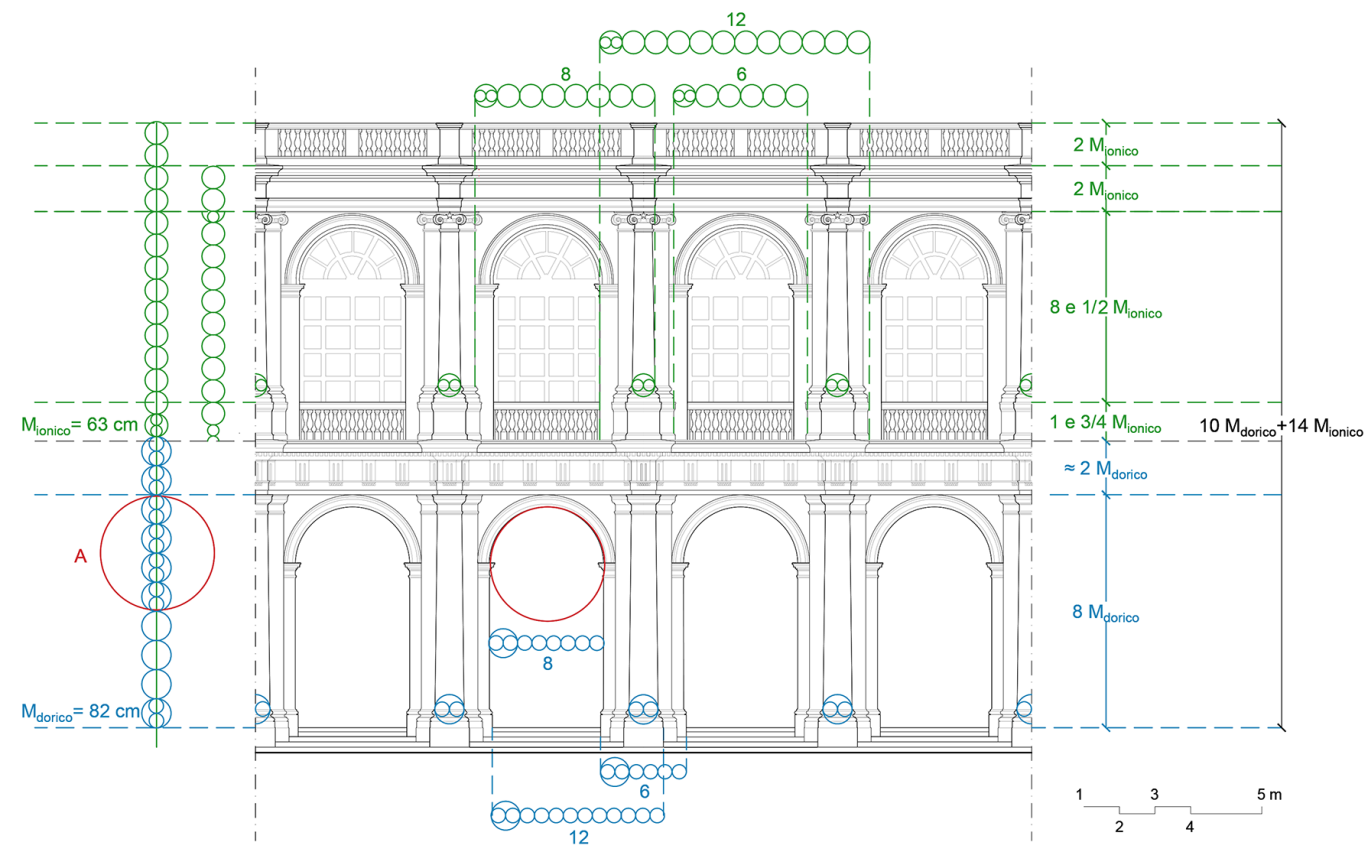

Per l'ordine ionico, invece, il piedistallo è alto un modulo $(63 \mathrm{~cm})$ e 3/4, la colonna, comprensiva di base e capitello, 8 moduli e mezzo (anziché 9, come avviene classicamente) e la trabeazione 2 moduli. II parapetto della terrazza soprastante, anch'esso proporzionato secondo l'ordine ionico, misura invece 2 moduli. Per quanto riguarda le suddivisioni orizzontali, è possibile distinguere un rapporto armonico: la distanza tra i piedistalli di una campata è 6 volte il modulo, quella tra la parasta esterna e la colonna centrale successiva è 8 moduli, mentre la distanza tra il piedritto dell'arco e il piedistallo della campata seguente misura 12 moduli.

Per l'ordine dorico, invece, è individuabile una proporzione armonica tra la larghezza totale delle basi $(2,40 \mathrm{~m})$, la luce delle arcate $(3,20 \mathrm{~m})$ e la distanza tra la base del piedritto e la base della colonna centrale seguente $(4,80 \mathrm{~m})$. A differenza dell'ordine ionico, tuttavia, la proporzione armonica lega tali dimensioni, con lo scarto di I cm, al raggio della colonna (4I $\mathrm{cm}$ ) invece che al diametro.

Infine, è interessante notare come le irregolarità nel proporzionamento dei due ordini architettonici (la trabeazione nel dorico e il piedistallo nello ionico) si vengano a compensare una volta sommate tra loro: nel momento in cui i due ordini vengono sovrapposti, il doppio loggiato diventa alto 10 moduli dorici più 14 moduli ionici. Questo a dimostrare che il proporzionamento dei due ordini, seppure effettuato indipendentemente secondo il canonico rapporto col diametro della colonna, segua sempre una visione d'insieme del loggiato, che tenga conto dell'armonia data dalla relazione del due ordini sovrapposti. 


\section{Conclusioni}

II Palazzo delle Finanze nasce sotto le decisive pressioni del potente ministro Sella che, reputata insoddisfacente l'opzione di utilizzare vecchi immobili riadattati, riteneva necessaria la costruzione di un edificio ex novo che ben rappresentasse il nuovo Stato italiano che andava ad insediarsi, di diritto, nella sua nuova capitale. La realizzazione dell'edificio, pertanto, si inseriva in un contesto più ampio, che richiamava la visione politica, oltreché architettonica, che Sella aveva della Roma Capitale.

La scelta tipologica della reggia, molto in voga sin dal Settecento nel mondo neoclassico italiano, oltre a prestarsi alle enormi dimensioni dell'edificio, ben si sposava con l'intento celebrativo che vi era alla base della sua realizzazione.

Nel solco della rappresentatività va letta, anche, la scelta di ricorrere agli stilemi del linguaggio classico per trattare dal punto di vista architettonico l'enorme volumetria del nuovo edificio. Non volendo sperimentare scelte figurative nuove, si preferì affidarsi ad un lessico consolidato, che si andava a porre in continuità con l'architettura della Roma dei papi.

Nonostante le intenzioni del Sella, tuttavia, il Palazzo delle Finanze è un edificio che non suscitò mai particolare apprezzamento, né da parte dei contemporanei né da parte della storiografia moderna [Portoghesi 1962]. Gli si rimprovera una scarsa qualità formale, le cui motivazioni sono riconducibili all'assenza di una figura di spessore che ne curasse l'intero processo progettuale.

A Canevari - ingegnere senza esperienze in campo architettonico - spettava il compito di coordinare il complesso iter e di mediare le pressanti richieste di Sella. II suo contributo progettuale era volto alla definizione dell'impostazione generale (impianto planimetrico e strutturale) e alla gestione delle complicate vicende del cantiere, legate soprattutto a problemi con il sottosuolo e le fondazioni. La figuratività dell'edificio viene quindi affidata ad altri: scelto il linguaggio architettonico da adottare nella fase preliminare, i dettagli vengono 'solo disegnati' da architetti coinvolti, principalmente, per rispondere alla pressante esigenza del cantiere di avere disegni esecutivi.

È per tale ragione che del progetto della corte centrale viene incarico Pieroni. Formatosi come rilevatore di monumenti, Spagnesi fatica a vedere in lui un vero e proprio progettista ma, piuttosto, lo etichetta come un semplice 'disegnatore' delle facciate interne.

Tale ruolo, tuttavia, può essere riletto in una chiave diversa, limitandone la valenza riduttiva. Migliari [Migliari 199I], infatti, sottolinea come l'armonia dell'ordine architettonico risieda nelle proporzioni tra i singoli elementi, per le quali strumento basilare è il disegno: è solo attraverso il disegno che si riesce ad ottenere agevolmente i rapporti proporzionali tra le singole parti, mantenendo il controllo delle gerarchie che le legano. Attraverso il disegno, dunque, si modellano le proporzioni degli elementi costitutivi dell'ordine architettonico e, così facendo, si progetta l'architettura.

Fig. 9. Base attica dell ordine dorico: in di proporzionamento di proporzionamento vitruviano, le dimension degil elementi sono stat successive.

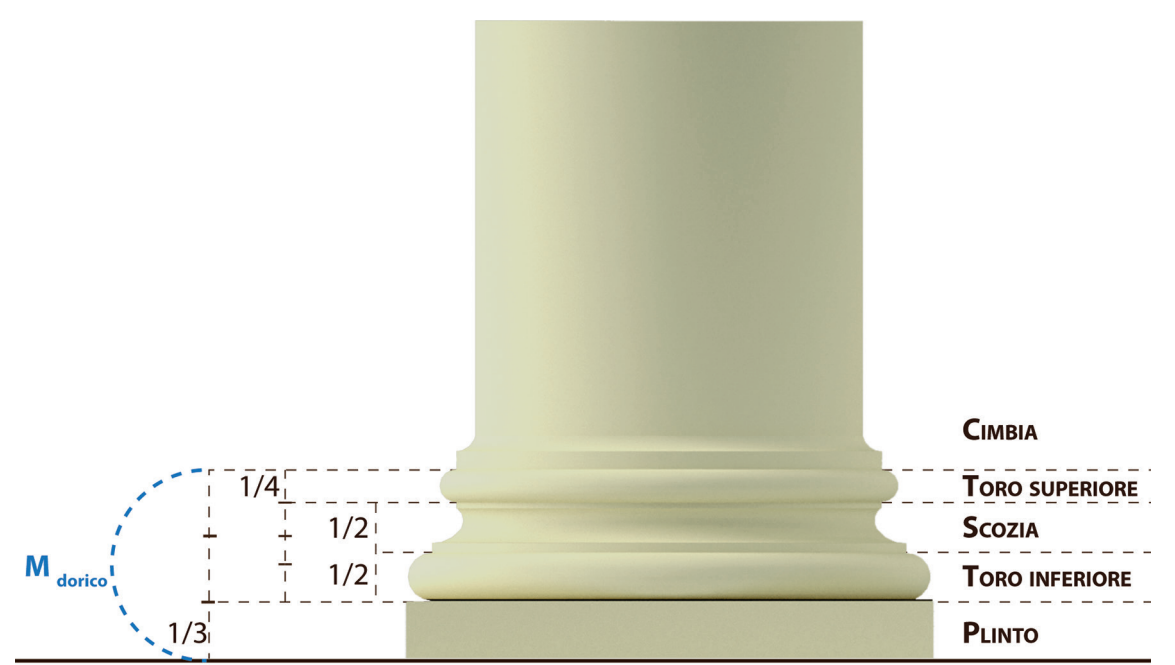


In tal senso, proprio in qualità di 'disegnatore', la figura di Pieroni può assumere una connotazione differente all'interno del complesso iter progettuale e realizzativo del Palazzo delle Finanze.

Seppur seguendo le indicazioni ricevute e senza particolari guizzi creativi, le facciate disegnate da Pieroni possono essere viste come qualcosa di più di un mero esercizio di stile in cui egli, data la sua formazione di rilevatore, poteva eccellere. Esse rispondono allistanza celebrativa che, posta in particolare da Sella, è stata alla base dell'intero intervento.

Sapientemente disegnato secondo i rassicuranti stilemi del linguaggio classico, pertanto, il loggiato, insieme alla fontana centrale (anch'essa opera di Pieroni), è pensato per soddisfare la funzione rappresentativa del palazzo e, in particolare, della grande corte d'onore.

\section{Riferimenti bibliografici}

AA.W. ( 1 989). Il Palazzo delle Finanze e del Tesoro. Roma: Editalia.

Bianchini Carlo (20I4). Survey, Modeling, Interpretation as multidisciplinary components of a knowledge system. In SCIRES-IT, $4,1,2014$, pp. 15-24

Consoli Gian Paolo, Pasquali Susanna (2005). Roma: L'architettura della capitale. In Restucci Amerigo (a cura di). Storia dell'architettura italiana. L'Ottocento. Mondadori Electa, pp. 1094.

Docci Mario, Maestri Diego (2009). Manuale di rilevamento architettonico. Bari: Editori Laterza.

Gaiani Marco (20I2). Per una revisione critica della teoria del rilievo dopo l'avvento dei mezzi digitali. In Carlevaris Laura, Filippa Monica. Elogio della teoria. Identità delle discipline del disegno e del rilievo. Roma: Gangemi Editore.

Migliari Riccardo (| 99| ). Il disegno degli ordini e il rilievo dell'architettura classica: Cinque Pezzi Facili. In Disegnare. Idee immagini, 2, p. $35-47$.

Polla Ermanno (1979). Il Palazzo delle Finanze di Roma capitale. Roma: Istituto Poligrafico e Zecca dello Stato.

Portoghesi Paolo (1962). L'Eclettismo A Roma. 1870-1 922. Roma: De Luca.

Salsano Fernando (20 I 2). I costi di Roma Capitale: il trasferimento dell'amministrazione centrale e lo sviluppo della città ( I 87 | |88I). In Città e Storia,VII, 2012, 2, pp. 219-237.

Tabarrini Marisa (20 I I). I ministeri di Roma Capitale. In Mangone Fabio, Tampieri Maria Grazia (a cura di). Architettare I'Unità. Architettura e istituzioni nelle città della nuova Italia 186/ - 1911. Catalogo della mostra, Roma, Casa dell'Architettura, 27 aprile 25 maggio 20 I I. Napoli: Paparo edizioni, pp. 31-38.

Vannelli Valter (200 I). Roma, architettura. Da città dei papi a capitale d'Italia. Roma: Edizioni Kappa.

\section{Autore}

Pamela Maiezza, Università degli Studi dell'Aquila, pamela.maiezza@univaq.it

Per citare questo capitolo: Maiezza Pamela (2020). Un cortile per una nuova capitale/A courtyard for a new capital. In Arena A., Arena M., Brandolino R.G., Colistra D., Ginex G., Mediati D., Nucifora S., Raffa P. (a cura di). Connettere. Un disegno per annodare e tessere. Atti del $42^{\circ}$ Convegno Internazionale dei Docenti delle Discipline della Rappresentazione/Connecting. Drawing for weaving relationships. Proceedings of the 42th International Conference of Representation Disciplines Teachers. Milano: FrancoAngeli, pp. 3835-3854. 


\title{
A Courtyard for a New Capital
}

\author{
Pamela Maiezza
}

\section{Abstract}

The transfer of the capital to Rome, following the annexation of the Popes' City to the Kingdom of Italy, posed the problem of identifying the spaces where to host the administrative bodies of the State.

Once the first phase marked by the urgency to make effective the national government establishment and by the using of the Papal State offices or converted ecclesiastical buildings, had been overcome, the need to make strategic choices for the establishment of Rome Capital emerged.

The Palazzo delle Finanze (| 87| - | 876), built at the behest of Minister Quintino Sella by a group of designers coordinated by Raffaele Canevari, constitutes the first public work created from scratch to respond to the functional and representative needs of the new unitary state.

The proposed contribution presents the study conducted on the Palazzo, focusing attention on the central courtyard designed by Francesco Pieroni. Based on the architectural survey, a historical-critical reading of the courtyard is proposed through, in particular, the proportional analysis of the architectural order of the loggia.

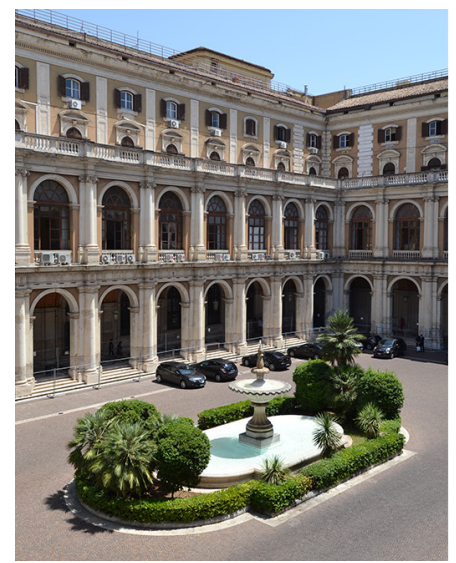

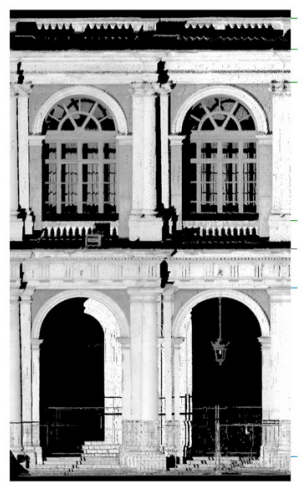

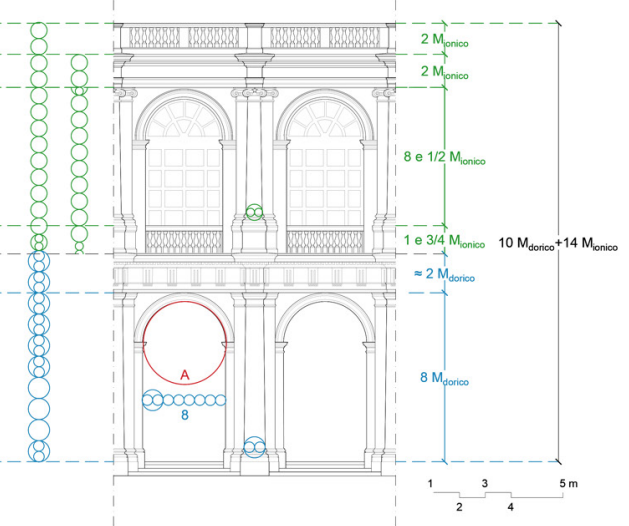




\section{Introduction}

The transfer of the capital from Florence to Rome in $187 \mid$, following the annexation of the Popes' City to the Kingdom of Italy, posed the problem of identifying the spaces where to host the administrative bodies of the State.

A first stage marked by the urgency of making effective the settlement of the Italian national government, in which the offices of the Papal States or converted ecclesiastical buildings were provisionally used, was followed by a more reflective and programmatic one, in which the need to make strategic choices for the establishment of Rome Capital emerged [Borsi 1989; Salsano 20 I2].

The Palazzo delle Finanze, built between I87 I and I876 by a group of designers coordinated by Raffaele Canevari, represents the first public work built from scratch to meet this requirement (fig. I).

Strongly desired by Quintino Sella, Minister of Finance from 1862 who was the undisputed protagonist of this period, the Palace exemplifies his idea of the Public Administration and Rome Capital.

Not only a simple client of the headquarters of his Ministry, in fact, Sella played a role of primary importance in the construction of the Palazzo delle Finanze, actively participating in its construction process, enough to raise doubts about the authorship of the building: "Quintino Sella, 'engineer' for better or for worse, is the one to whom this work should probably be ascribed. The urbanistic choices, the selection of the architects and the working group are his, perhaps [...] in some way also the indication of the neo-sixteenth century language to be adopted is his" [Spagnesi 1989, p. 94].

Within the convention signed in 2017 between the University of L'Aquila and the Ministry of Economy and Finance relating to the Study of the behavior under seismic loads of the building of the Ministry of Economy and Finance in via XX Settembre - Rome (Scientific Director professor Angelo Luongo), the architectural survey of the central courtyard of the Palace, the gallery on the first floor in the two accessible arms and the Sala della Maggioranza, now called the Sala Ciampi, was carried out.

The proposed contribution presents part of the results of this study, focusing attention on the central courtyard designed by Francesco Pieroni. Specifically, based on the architectural survey a historical-critical reading of the courtyard is proposed, in particular through the proportional analysis of the architectural order of the loggia.
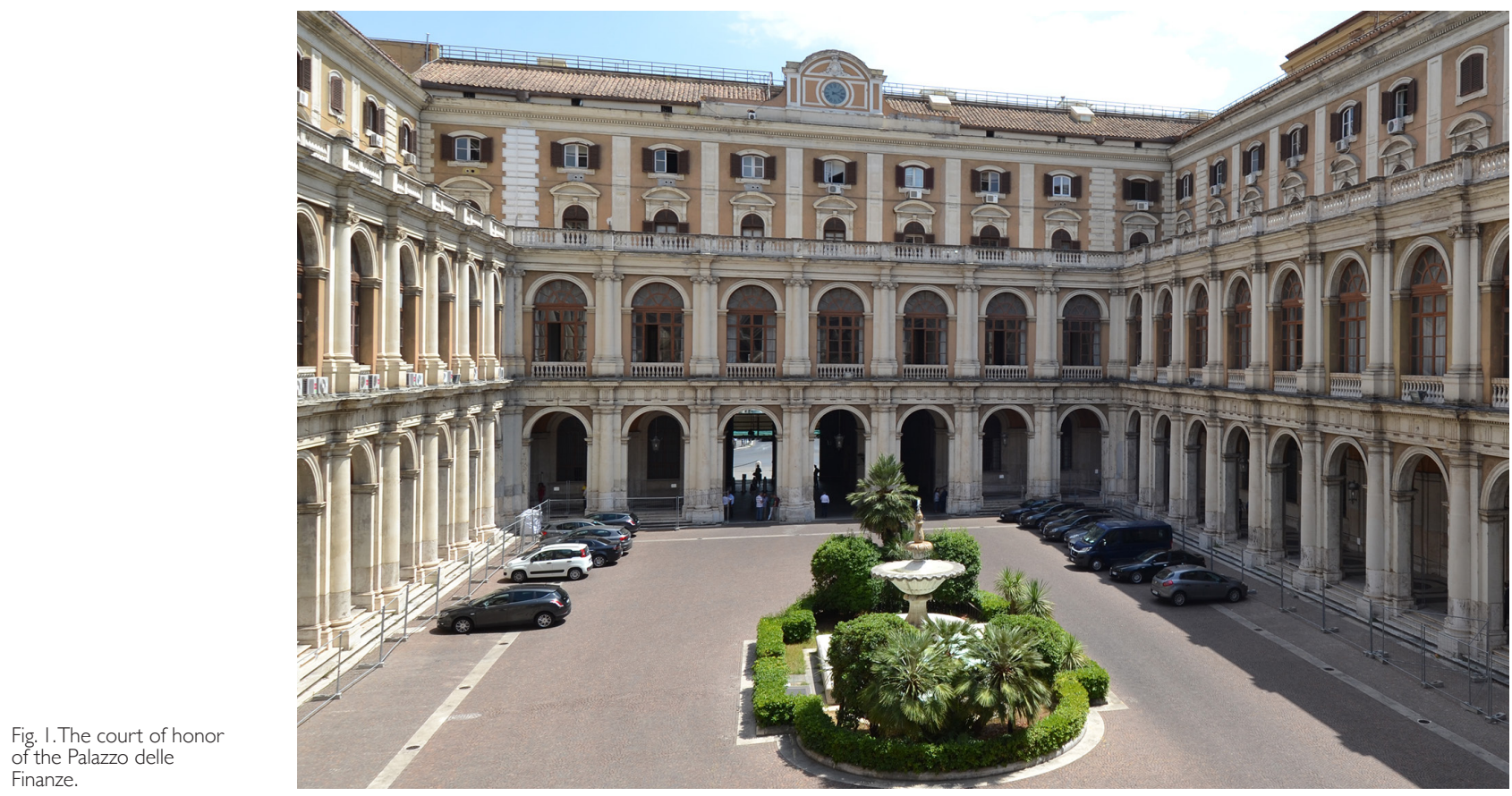


\section{From the Rome of the Popes to Rome Capital: the construction of the Palazzo delle Finanze}

The construction of the Palazzo delle Finanze is part of the debate about the methods to be followed for the establishment of Rome Capital, which sees two different orientations: the first based on the redesign of old expropriated buildings, and motivated by economic and urgent reasons; the other focused on the creation of a new business center along the axis of via XX Settembre, as a symbol of united Italy and its new capital [Tabarrini 20 I I]. This second approach, supported by the first Commission for the capital transfer as well as by the powerful Minister Sella, inevitably interferes with the urban plans for the expansion of the city to the east, carried out independently by the Capitoline administration. The project for the new district of Macao, which started in 1860 in relation to the new Termini Station, will necessarily have to change in order to comply with Sella's choice to place the gigantic Ministry building in the heart of the neighborhood, along Via XX Settembre.

The design of the building was initially entrusted to the Milanese engineer Luigi Tatti, flanked by the Roman Raffaele Canevari. Although Tatti was relieved of his duties between October and November I 87I, the exact location of the new building in the Macao district and, above all, the typological solution of the palace, which will then be adopted in the final project, are due to the Milanese engineer.

The assignment for the Ministry of Finance then passed to Canevari, a railway and hydraulic engineer with little experience in the architectural sector who, however, had a good knowledge of Rome and of the municipal projects, derived from his involvement in the debate on urban development carried out by the municipal administration. In October 1872 he was joined by two architects, Luigi Martinori and Francesco Pieroni, authors of the external facades and the central courtyard, respectively.

If no other Marinori's works are known, Pieroni already had to his credit several common buildings projects when he was called to collaborate in the construction of the Ministry. However, despite the high consideration that his contemporaries had of him, his works do not demonstrate the qualities of an architect who distinguishes himself from many of his colleagues: refined surveyor of monuments as he was (he had worked with Letarouilly), Pieroni must be considered more a drawer than a designer capable of proposing solutions for such a complex work as the Palazzo delle Finanze [Spagnesi 1989].

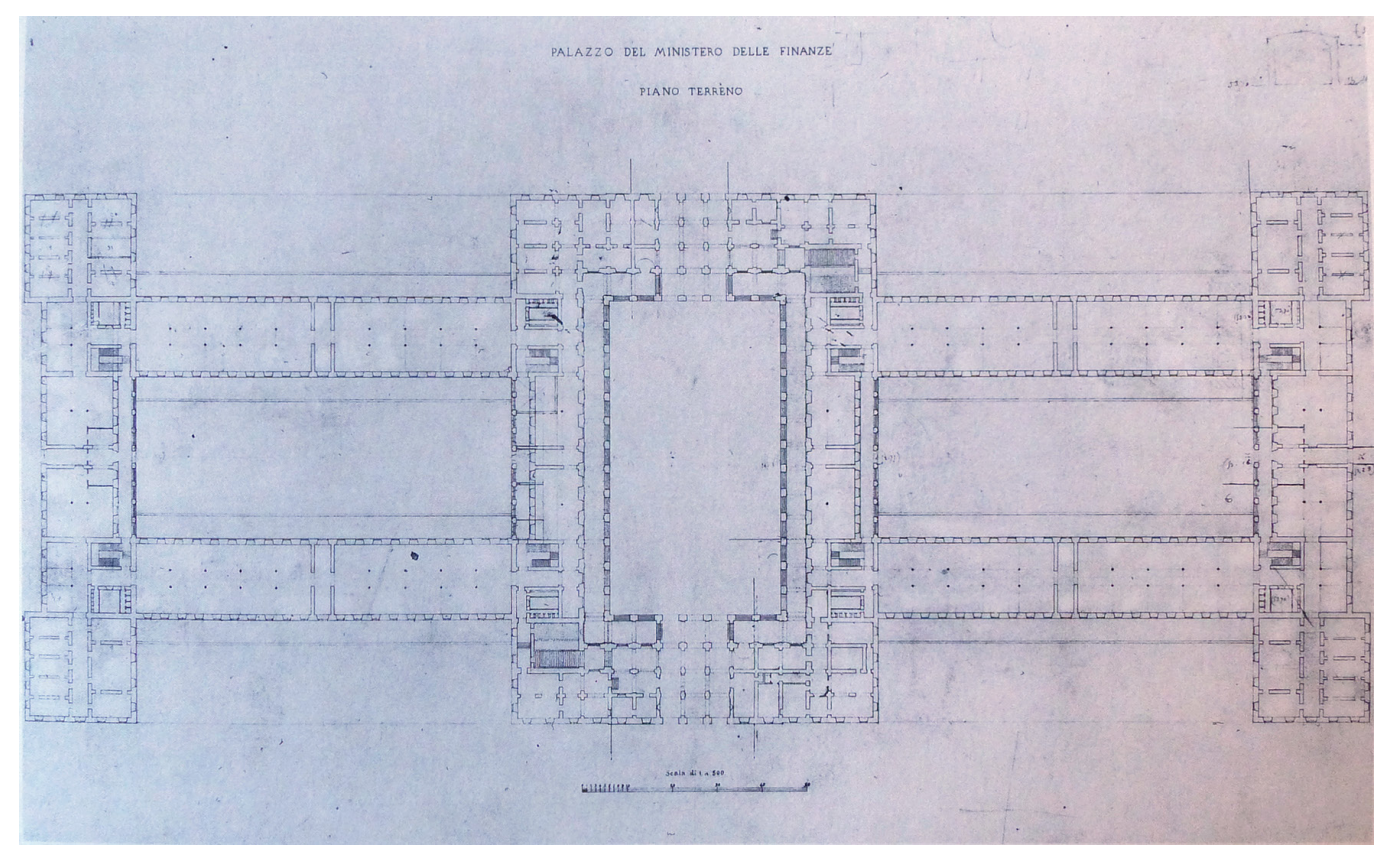


Then the setting of the work group with the relative division of roles, as desired by Sella itself, appears clear: once the typology of the new building has been decided by Tatti, Canevari will have the task of defining the distribution and structural system and the responsibility for the construction site, while the two architects will have to deal with the design of the architectural language details.

Canevari proposed three different design solutions, each divided into several variants, before arriving at the final configuration: a planimetric system characterized by a longitudinal course due to the elongated rectangular shape of the two lateral courtyards, separated from the courtyard of honor which, on the other hand, is characterized by a transverse position given to it by the advancement of the fronts up to the edge of the four corner towers [Polla 1979] (fig. 2).

As regards the chosen architectural language, no attempt was made to propose a completely new figurativity but, rather, it was preferred to refer to the neo-sixteenth century, in continuity with that Roman "purism" that had characterized architecture during the pontificate of Pius IX (fig. 03).

Work began on I th April 1872, when the project had not yet taken its final form.

Right from the start, however, Carnevari was faced with serious problems, in particular related to the building foundations. The presence of important archaeological pre-existences -as indeed it was obvious to expect- and of voids (natural caves or excavated tunnels), typical of Roman soil, required deeper foundations than those planned, thus leading to significant delays to the construction site and to a substantial increase in expenses.

Due to the urgency to install the ministerial offices in the new building as soon as possible, a first testing of the parts already completed was carried out on 12th September 1876. The inauguration of the Palazzo delle Finanze, still incomplete, took place on 3th September 1877, while a second provisional testing will take place on 16th July 1878. Only on 6th June 188 I, however, the final testing of the entire building was performed.

At the end of the works, Sella's idea of establishing a new administrative center on the axis between Porta Pia and the Quirinale (along via XX Settembre), of which the Palazzo delle Finanze was only the first step, even if the main one, was abandoned because of the lack of funds, now exhausted.

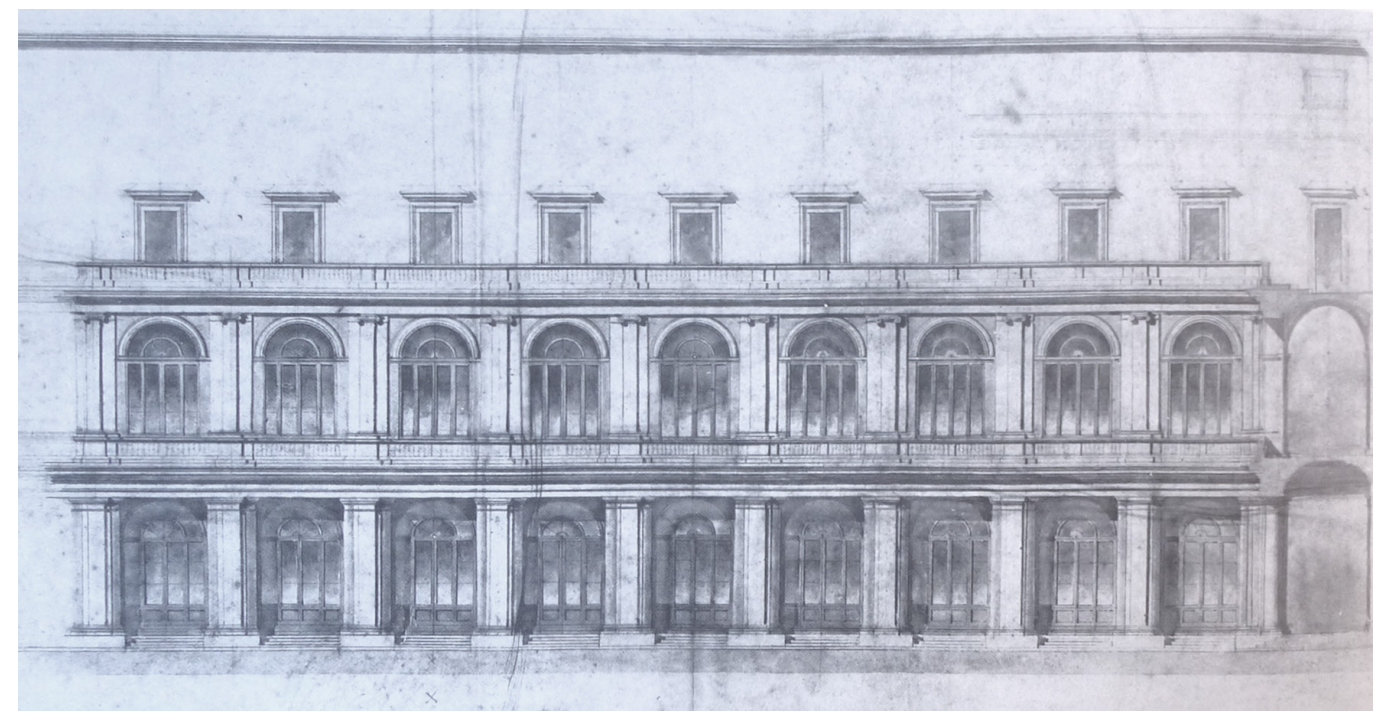

\section{The architectural survey}

The survey campaign of the Palazzo delle Finanze was conducted with the aid of the phase difference laser scanner Leica HDS6200, characterized by a full field of view (FOV) of $360^{\circ} \times 310^{\circ}$ (fig. 4). 


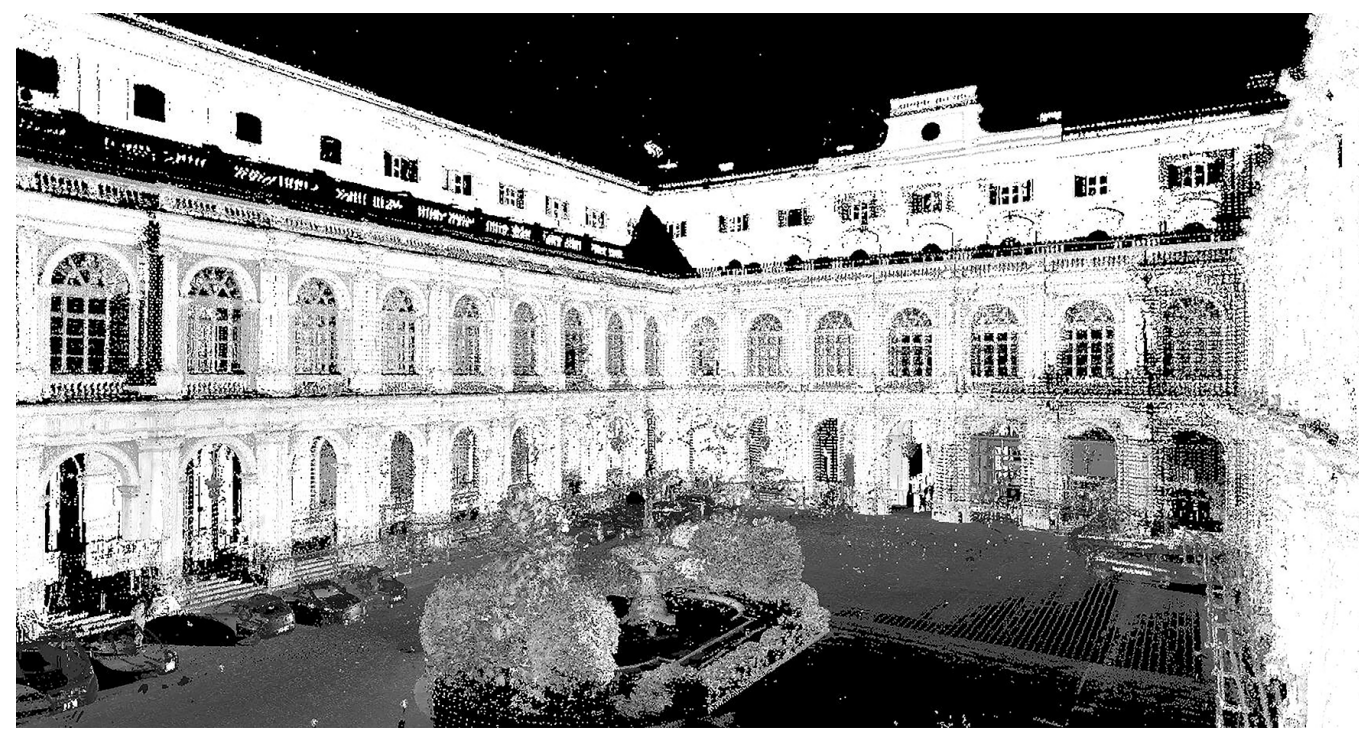

The survey project, with the definition of scanning station and the scan resolution, was conditioned by the need to reduce data acquisition times as much as possible.

Having a limited time available to access the Ministry spaces, it was in fact necessary to optimize the scan times without, however, losing the accuracy of the scan or completeness of the information.

In consideration of the geometric-dimensional characteristics of the environments to be surveyed, it was decided to adopt the high resolution level for the courtyard and the Sala Ciampi (corresponding to an increase in azimuth and zenith angle of $0.036^{\circ}$ and a distance between the points, for example, of $1.59 \mathrm{~cm}$ at $25 \mathrm{~m}$ ), and the average one (increase in azimuth and zenith angle of $0.072^{\circ}$ and a point density of $3.14 \mathrm{~cm}$ at $25 \mathrm{~m}$ ) for the gallery on the first floor.
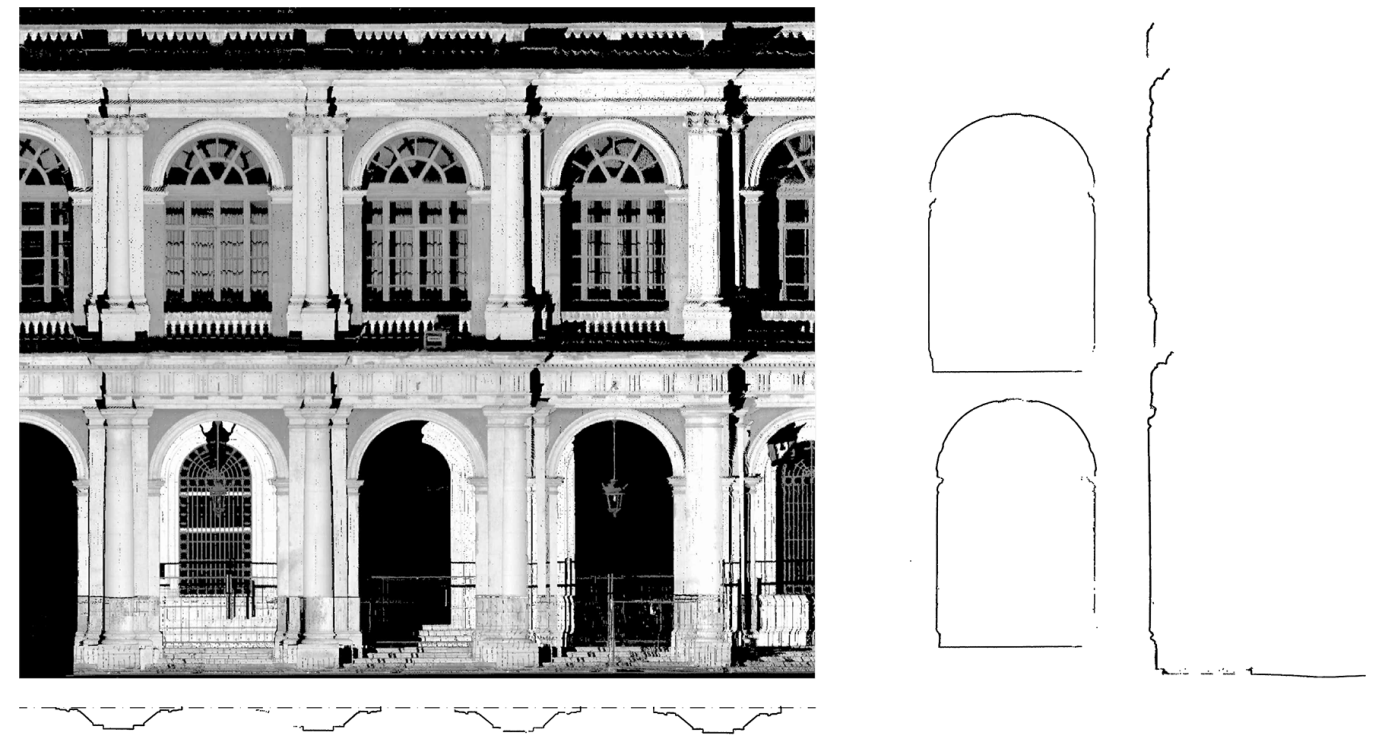

Fig. 5. Point cloud of the loggia: orthophoto, vertical and horizontal vertical
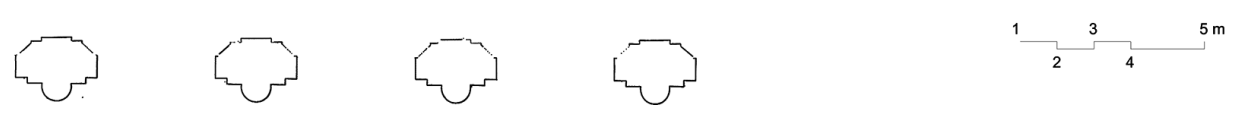
A total of 18 scans were created, divided as follows: 9 laser shots in the gallery on the first floor; 3 inside the Sala Ciampi; 6 inside the courtyard.

The registration of the individual scans was carried out mainly by means of automatic recognition procedures of the mobile targets, positioned before shooting so that they were visible from two adjacent scans. Specifically, 6"Tilt \& Turn targets of the Black \& White type were used, which ensure front visibility from each scanning station.

For the connection between external and internal, however, since it was not possible to insert a sufficient number of targets, we proceeded with manual registration operations, which consisted in identifying a series of homologous points between the two point clouds obtained by the automatic registration of indoor and outdoor scans.

The overall point cloud thus obtained was then used for the realization of the two-dimensional restitutive drawings (fig. 5).
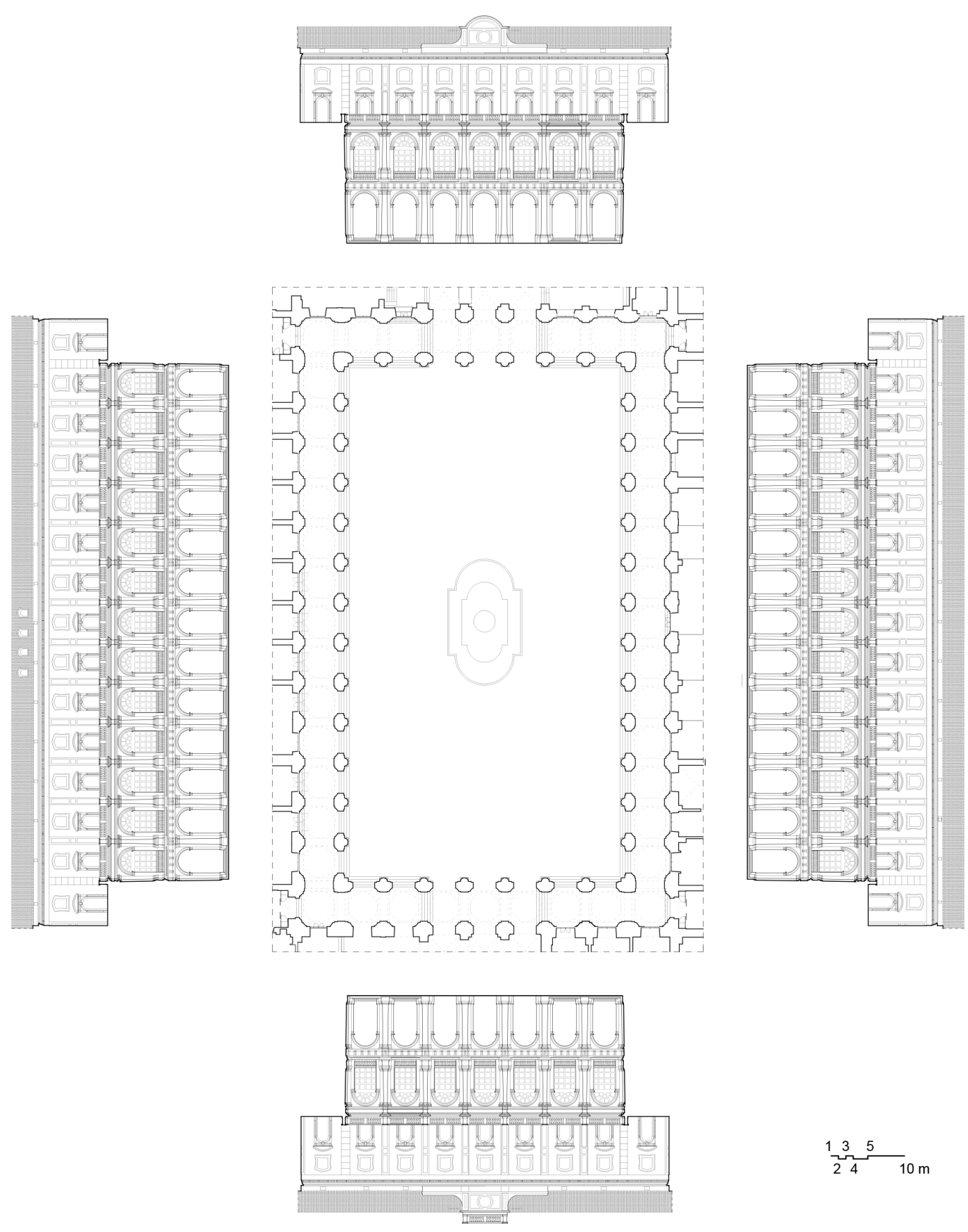
For the plan representation, in particular, the point cloud was sectioned with a cutting plane passing at a height of two meters above the level of the courtyard flooring. The projected portions were instead drawn on the basis of the ortho-image obtained from the point cloud through the same section plane. The elevations on the courtyard, instead, were obtained by passing section planes parallel to the individual facades of interest: the slice of the point cloud served as a support for identifying the profiles of the architectural elements and the moldings; the ortho-image was instead used for the design of the architectural order in orthogonal projection (fig. 6).

\section{The central courtyard: analysis and proportions of the court of honor}

The large representative court designed by Francesco Pieroni constitutes the fulcrum around which the entire plan of the Palazzo delle Finanze gravitates: played on the articulation of the courts, the plan is in fact marked by a strong transversal axis consisting of the central courtyard, which is opposed to the longitudinal position of the building.

Looking at the different projects designed for the Palazzo delle Finanze, the evolution of the role of the central courtyard is clear, from a simple widening with a mere functional value to a real court of honor: if in the first project ( $187 \mid$ ) the very large square-shaped side courtyards are just spaced from a very narrow central courtyard, already in the second project $(|87|)$ this becomes more important, with a cruciform plant very protruding on the fronts (first variant), or aligned with the corner towers (second variant ); in the third project the articulation of the courtyard is renounced, which remains, however, still rather narrow and cramped, finally arriving, in the second variant, at its definitive shape with proportions that make it the representative courtyard of the building [Spagnesi 1989].

Various hypotheses are elaborated for the definition of the architectural language of the facades on the courtyard. However, all hypotheses maintain the basic idea of a two-storey loggia characterized by a double superimposed order or by a giant order that frames two levels of arches. In the end, among the various possibilities it was decided for the overlap of the lonic order with the Doric one, a solution chosen before the involvement of Pieroni who was given, therefore, only the task of the final design.

Trained by surveying the monuments of Roman Renaissance architecture, Pieroni proposed a rather scholastic solution based on the models of the mature sixteenth century.

The fronts facing the courtyard have a regular step marked by a constant rhythm on all four sides, except for the corner span, slightly narrower (about $10 \mathrm{~cm}$ ).

Fig. 7. Proportional analysis of the loggia: the height measured from the base of the piers up to the entablature of the second order is equal to 5 times the arches span (module A); instead, starting from the base of the central column, the loggia is three times the interaxle spacing of the interaxle spacing of
pillars (module B).

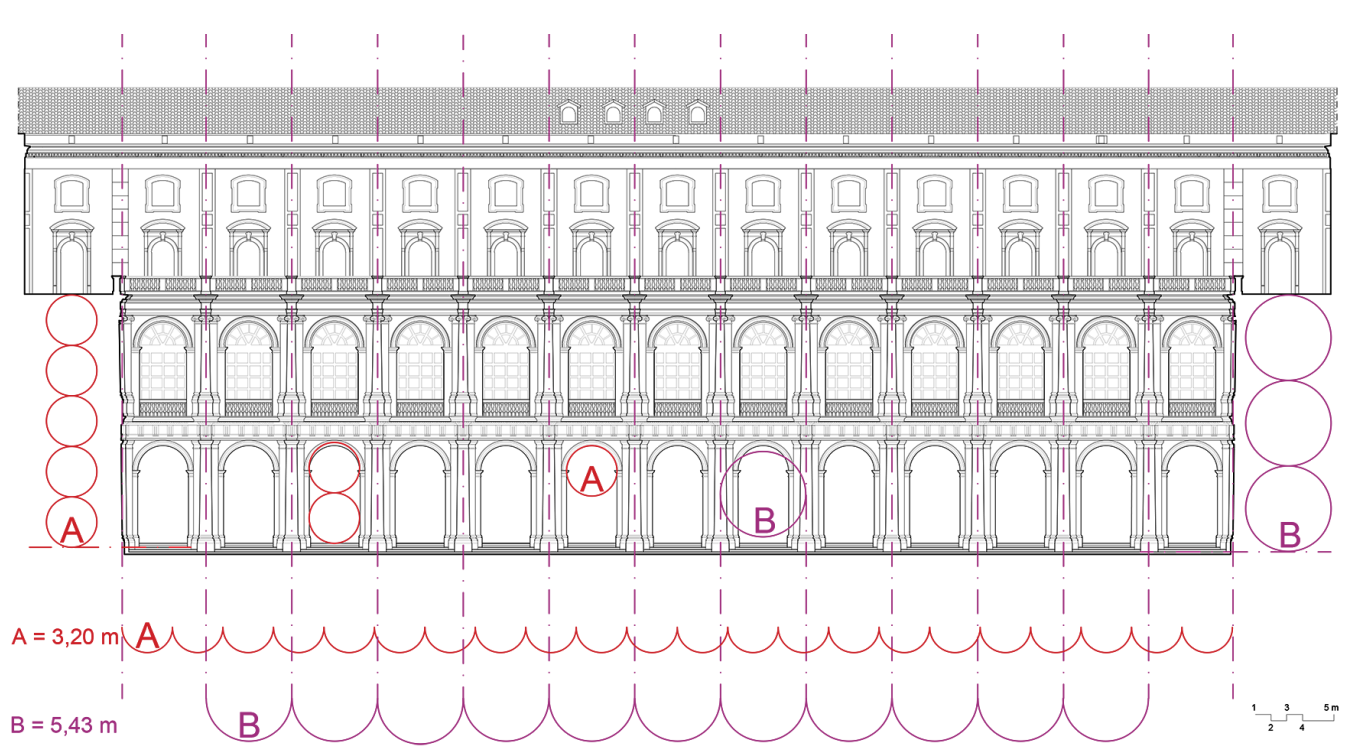


Fig. 8. The proportions of the double architectura order: Doric module $(82 \mathrm{~cm})$, lonic module harmonic proportion $(6,8,12)$
The Doric order frames the arches of the ground floor portico, while the second order, in lonic style with a pedestal, frames the large arched windows of the first level. Both orders have an Attic base (fig. 9).

Defined as module $A$ the span of the arches, the height of the loggia measured from the base of the piers up to the entablature of the second order is equal to 5 modules. Instead, starting from the base of the central column, the loggia is three times the interaxle spacing of the pillars (module B) (fig. 7).

The proportions of the order are the classic ones traceable in the Renaissance architectural treatises, except for some exceptions.

In particular, taking as a module the diameter of the column assessed at the lower scape (equal to $82 \mathrm{~cm}$ ), the Doric order measures 8 modules from the base up to the capital and almost 2 modules for the entablature (fig. 8).

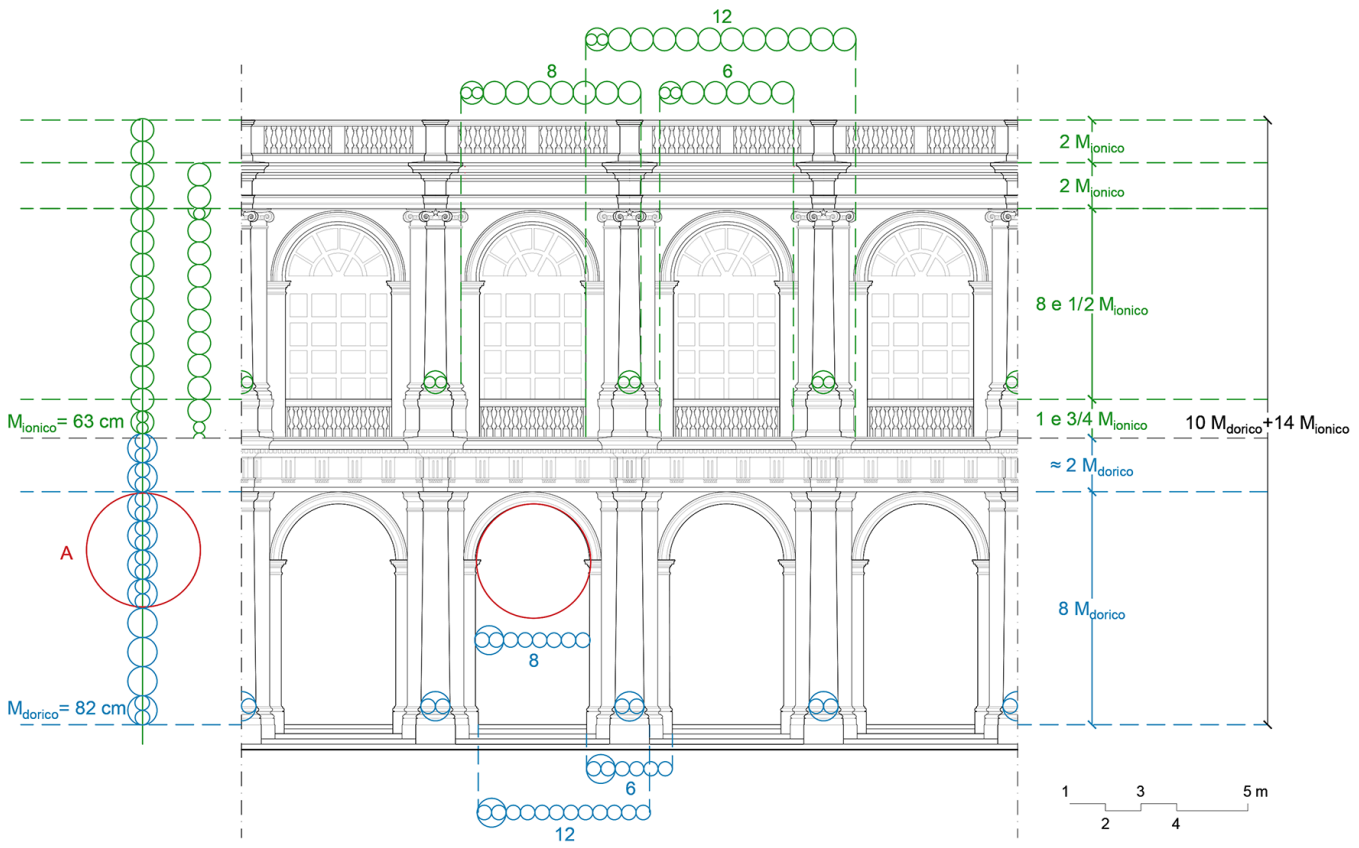

For the lonic order, instead, the pedestal is one module $(63 \mathrm{~cm})$ and $3 / 4$ tall, the column, including the base and capital, 8 modules and a half (instead of 9 as is usual) and the entablature 2 modules. The parapet of the terrace above, also proportioned according to the lonic order, measures 2 modules instead. As for the horizontal subdivisions, it is possible to distinguish a harmonious relationship: the distance between the pedestals of a span is 6 times the module, that between the external pilaster and the next central column is 8 modules, while the distance between the arch pier and the pedestal of the following span measures 12 modules.

For the Doric order, instead, a harmonic proportion can be identified between the total width of the bases $(2.40 \mathrm{~m})$, the span of the arches $(3.20 \mathrm{~m})$ and the distance between the base of the pier and the base of the central column following $(4.80 \mathrm{~m})$. Unlike the ionic order, however, the harmonic proportion links these dimensions, with the difference of I cm, to the radius of the column $(4 \mathrm{I} \mathrm{cm})$ instead of the diameter.

Finally, it is interesting to note that the irregularities in the proportioning of the two architectural orders (the entablature in the Doric and the pedestal in the lonic) are compensated once added together: when the two orders are superimposed, the double loggia becomes high I 0 Doric modules plus I 4 ionic modules. This demonstrates that the proportioning of the two orders, although carried out independently according to the canonical relationship with the column diameter, always follows an overview of the loggia, which takes into account the harmony given by the relationship of the two superimposed orders. 


\section{Conclusions}

The Palazzo delle Finanze was born under the decisive pressure of the powerful Minister Sella who, considered unsatisfactory the option of using old converted buildings, believed it was necessary to realize a new building that well represented the new Italian state that was going to settle, by right, in his new capital. The construction of the building, therefore, was part of a wider context, which recalled the political, as well as architectural, vision that Sella had of the Rome Capital.

The typological choice of the palace, very popular since the eighteenth century in the Italian neoclassical world, in addition to lending itself to the enormous dimensions of the building, matched with the celebratory intent that was at the basis of its construction.

Even the choice to use the stylistic features of the classical language to treat the huge volume of the new building from an architectural point of view should be read in the wake of representativeness. Not wanting to experiment with new figurative choices, a consolidated lexicon that was in continuity with the architecture of the Popes' Rome was preferred.

Despite Sella's intentions, however, the Palazzo delle Finanze is a building that never aroused particular appreciation, neither from contemporaries nor from modern historiography (Portoghesi 1962). It is reproached for a lack of formal quality, the reasons for which are attributable to the absence of a figure of substance who took care of the entire design process.

Canevari -an engineer with no experience in the architectural field- was in charge of coordinating the complex process and mediating Sella's pressing requests. His design contribution was aimed at defining the general approach (planimetric but also structural) and managing the complicated events of the construction site, mainly linked to problems with the subsoil and foundations. The building figurativity is then entrusted to others: once the architectural language to be adopted has been chosen in the preliminary phase, the details are 'only drawn' by architects involved mainly to respond to the construction site pressing need for executive drawings.

It is for this reason that Pieroni was commissioned to design the central court. Trained as a surveyor of monuments, Spagnesi struggles to see him as a real designer but, rather, he labels him as a simple 'drawer' of the internal facades.

However, this role can be reread in a different key, limiting its reductive value.

Migliari [Migliari 1991], in fact, underlines how the harmony of the architectural order lies in the proportions between the individual elements, for which the basic tool is the drawing: it is only through the drawing that it is possible to easily obtain the proportional relationships between the individual parts, keeping control of the hierarchies that bind them. Through the drawing, therefore, the proportions of the constituent elements of the architectural order are modeled and, in doing so, the architecture is designed.

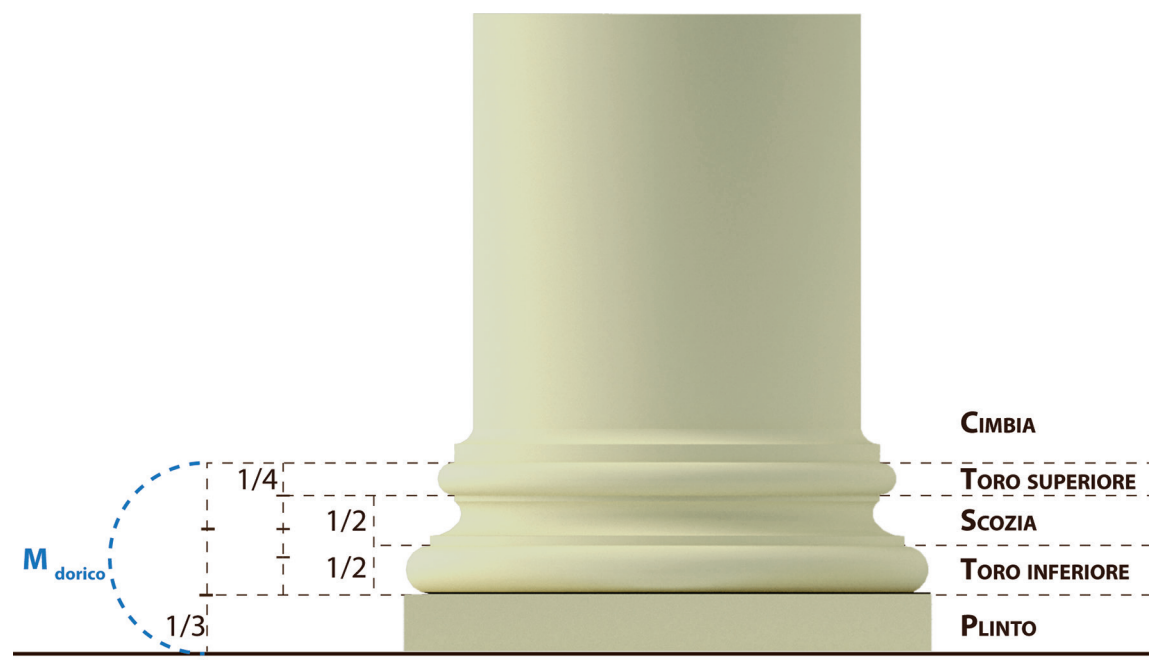


In this sense, precisely as a 'drawer', the figure of Pieroni can take on a different connotation within the complex design and construction process of the Palazzo delle Finanze.

Although following the indications received and without particular creative flairs, the facades designed by Pieroni can be seen as something more than a mere exercise in style in which, given his background as a surveyor, he could excel.They respond to the celebratory request that, posed in particular by Sella, was the basis of the entire intervention.

Expertly designed according to the reassuring stylistic features of the classical language, therefore, the loggia, together with the central fountain (also by Pieroni), is designed to satisfy the representative function of the building and specifically of the great court of honor.

\section{References}

AA.W. ( 1989). II Palazzo delle Finanze e del Tesoro. Roma: Editalia.

Bianchini Carlo (20I4). Survey, Modeling, Interpretation as multidisciplinary components of a knowledge system. In SCIRES-IT, 4, I, 2014, pp. 15-24.

Consoli Gian Paolo, Pasquali Susanna (2005). Roma: L'architettura della capitale. In Restucci Amerigo (a cura di). Storia dell'architettura italiana. L'Ottocento. Mondadori Electa, pp. 1094.

Docci Mario, Maestri Diego (2009). Manuale di rilevamento architettonico. Bari: Editori Laterza.

Gaiani Marco (20I2). Per una revisione critica della teoria del rilievo dopo l'avvento dei mezzi digitali. In Carlevaris Laura, Filippa Monica. Elogio della teoria. Identità delle discipline del disegno e del rilievo. Roma: Gangemi Editore.

Migliari Riccardo ( 199 |). Il disegno degli ordini e il rilievo dell'architettura classica: Cinque Pezzi Facili. In Disegnare. Idee immagini, 2, p. $35-47$.

Polla Ermanno ( 1979). Il Palazzo delle Finanze di Roma capitale. Roma: Istituto Poligrafico e Zecca dello Stato.

Portoghesi Paolo (1962). L'Eclettismo A Roma. 1870-1922. Roma: De Luca.

Salsano Fernando (20 I2). I costi di Roma Capitale: il trasferimento dell'amministrazione centrale e lo sviluppo della città ( I87 | |88I). In Città e Storia,VII, 20 I2, 2, pp. 219-237.

Tabarrini Marisa (20 I I). I ministeri di Roma Capitale. In Mangone Fabio, Tampieri Maria Grazia (a cura di). Architettare I'Unità. Architettura e istituzioni nelle città della nuova Italia 186 I - 191 I. Catalogo della mostra, Roma, Casa dell'Architettura, 27 aprile 25 maggio 20I I. Napoli: Paparo edizioni, pp. 3I-38.

Vannelli Valter (200 I). Roma, architettura. Da città dei papi a capitale d'Italia. Roma: Edizioni Kappa.

\section{Author}

Pamela Maiezza, Università degli Studi dell'Aquila, pamela.maiezza@univaq.it

To cite this chapter. Maiezza Pamela (2020). Un cortile per una nuova capitale/A courtyard for a new capital. In Arena A., Arena M., Brandolino R.G., Colistra D., Ginex G., Mediati D., Nucifora S., Raffa P. (a cura di). Connettere. Un disegno per annodare e tessere. Atti del $42^{\circ}$ Convegno Internazionale dei Docenti delle Discipline della Rappresentazione/Connecting. Drawing for weaving relationships. Proceedings of the 42th Internationa Conference of Representation Disciplines Teachers. Milano: FrancoAngeli, pp. 3835-3854. 
Connettere: un disegno per annodare e tessere è il tema pensato per il $42^{\circ} \mathrm{Con}$ vegno Internazionale della Unione Italiana per il Disegno 2020.

Connettere per mettere in stretta relazione, per ricollegare idee e fatti con suoi prodromi. Ritrovare il senso delle cose per connettere i frutti alla radice del pensiero.

Connettere per mettere in contatto, congiungere, unire; in un territorio che spesso è argomento di ponti, si vuol rilanciare un proposito di connessione diversa, non fisica ma culturale, una promozione del dialogo tra discipline, conoscenze e culture, per meglio comprendere il nostro Disegno.

Connettere per collegarsi e contaminarsi con discipline e saperi che possono apparire distanti ma che nel mondo della ricerca trovano nelle frange di confine importanti punti di contatto e di rilancio.

Connettere per pensare al futuro; non uno qualsiasi, ma un futuro legato alla possibile evoluzione della Rappresentazione nel tempo che stiamo vivendo, augurandoci un domani sempre più fertile e sostenibile per le nostre ricerche.

Riportando le nostre riflessioni sul Disegno, la connessione tra i saperi appare dunque una possibilità per riportare i ragionamenti nel quadro dei processi globali che ne evidenziano la complessità, ma anche la ricchezza e le potenzialità che questi possono assumere nel contesto del patrimonio di conoscenze di cui disporre e di cui avvalersi. Dal virtuale all'analogico, dal modeling alla interoperabilità, dalla fruizione dei beni culturali alla loro salvaguardia e valorizzazione, dai linguaggi grafici alle più ampie forme di comunicazione, le collaborazioni con altri settori scientifici si mostrano sempre più necessarie e stimolanti per una riflessione e per l'impostazione di un percorso di analisi anche di tipo epistemologico.

Connecting: drawing for weaving relationships is the theme conceived for the 42nd International Conference of Teachers of the Disciplines of Representation, planned for 2020.

Connecting for closely relating, for reconnecting ideas and facts with its prodromes. For again finding the meaning of things to connect the fruits at the root of thought.

Connecting for putting in contact, joining, uniting; in a territory that is often the subject of bridges, we want to relaunch a proposal for a different kind of connection, not physical, but cultural, a promotion of dialogue between disciplines, knowledge and cultures, for a better understanding of our Drawing.

Connecting for accessing and contaminating oneself with disciplines and knowledge that may seem distant but which in the world of research find, in border fringes, important points of contact and relaunch.

Connecting for thinking about the future; not just any future, but a future linked to the possible evolution of Representation in the time that we are living, hoping for an increasingly fertile and sustainable tomorrow for our research.

By reporting our reflections on Drawing, the connection between the fields of knowledge, therefore, appears to offer a possibility to bring the reasoning back into the framework of the global processes that evidence its reticularity, its complexity, but also the richness and the potential they can assume in the context of the cognitive heritage that is to be available and used. From virtual to analog, from modeling to interoperability, from the fruition of cultural assets to their preservation and enhancement, from graphic languages to the widest forms of communication, collaborations with other scientific sectors are increasingly necessary and stimulating for a reflection and for the setting up of a path of analysis, even epistemological. 